\title{
Empathy, deservingness, and preferences for welfare assistance: A large-scale online perspective-taking experiment
}

\author{
Alexander Bor* Gabor Simonovits ${ }^{\dagger}$
}

July 7,2021

\begin{abstract}
Online perspective-taking experiments have demonstrated great potential in reducing prejudice towards disadvantaged groups such as refugees or Roma. These experiments trigger the psychological process of empathy and evoke feelings of compassion. Meanwhile, a growing literature argues that compassion towards the poor is an important predictor of support for social welfare. This paper bridges these two literatures and predicts that perspective-taking with the poor could increase support for welfare assistance. This hypothesis is tested in a pre-registered experiment conducted on a large and diverse online sample of US citizens $(\mathrm{N}=3,431)$. Our results suggest that participants engaged with the perspective-taking exercise, wrote essays expressing strong emotions, but perspective-taking had no meaningful causal effect on general attitudes towards social welfare. We can confidently rule out effects exceeding 2 points on a 100-point scale. These results indicate that perspective-taking with a poor, deserving individual does not necessarily reduce stereotypes about the poor in general; nor does it change views towards redistributive policies.
\end{abstract}

Please cite the final version of this paper published in Political Behavior at https://doi.org/10.1007/s11109-021-09728-4

${ }^{*}$ Post-doc, Department of Political Science, Aarhus University. alexander.bor@ps.au.dk

${ }^{\dagger}$ Assistant Professor, Department of Political Science, Central European University. simonovitsg@ceu.edu 
A large and growing body of research in social psychology argues that empathy is a strong determinant of inter-group attitudes (Batson et al. 1997). Seeing the world through the eyes of a member of an ethnic minority or other disadvantaged groups can reduce prejudice towards these groups (Galinsky and Moskowitz 2000). Accordingly, the intuition is commonly that more empathy would make the world a better place (Bloom 2016). Senator Barack Obama famously stated in a commencement speech that he is more concerned about the "empathy deficit" than about the federal deficit (Obama 2006).

Recently, a number of carefully executed experimental studies used perspective-taking in order to reduce prejudice against members of the Roma minority in Hungary (Simonovits et al. 2018), refugees in the US (Adida et al. 2018) and transgender individuals (Broockman and Kalla 2016). The positive - and in some cases long-lasting - effect of these interventions is all the more surprising given that they were based on brief stimuli and, in most cases, no personal contact with out-group members.

In this paper, we report the results of a large-scale, pre-registered online experiment that we designed to probe the scope conditions of perspective-taking as an antidote to exclusionary attitudes. In particular, we hypothesized that if attitudes towards welfare assistance are at least partly driven by a lack of empathy towards the poor (Feldman et al. 2019 , van Oorschot 2002), then a treatment that prompts subjects to take the perspective of a poor individual could shift attitudes towards redistribution. For this reason, our experiment seeks to 1) expand the domain of research on perspective-taking, which has so far mostly focused on minorities and 2) to test whether preferences about redistribution - which have proven quite rigid in the literature (see e.g. Kuziemko et al. 2015) - can be influenced through enhancing empathy towards the poor.

Our experiment followed the footsteps of classic research on perspective-taking (e.g. Batson et al. 1997). Subjects in our treatment group were presented with a short vignette describing the story of a person facing extreme financial hardship, were instructed to think of how they personally would cope with the situation described in the vignette, and finally, were asked to write a short text describing their feelings. The perspective-taking task was designed to evoke empathy and compassion and was developed through a series of pilot studies. We evaluated the effect of this task using a large online survey experiment deployed to a diverse sample of American adults. 
Our findings can be characterized as precisely estimated null results. Using a composite index of redistributive attitudes as an outcome variable, we can confidently rule out effects exceeding 2 points on a 100-point scale. In additional analyses, we show that these null results are not due to shortcomings of the stimulus: Through an analysis of the corpora of treated and control essays, we show that subjects indeed engaged with the task. The mean lexical diversity of the essays is on par with US presidents' inaugural speeches, and a dictionary-based sentiment analysis shows large differences between the experimental groups on expressed anxiety, sadness, and concern for money and health. Self-reported measures of emotions also show that the task evoked feelings of anxiety and compassion. In contrast, we observe small and inconsistent effects of the treatment on stereotyping and general affect towards the poor. This suggests that affective and cognitive reactions to the hypothetical person depicted in the vignette did not generalize to the group that the target represented. In other words, the policies we used to measure support for welfare assistance might have been too distant from the situation depicted in the writing task.

Overall, our results point to potential limitations of perspective-taking as a silver bullet assumed to reduce group stereotypes or as a commonly used implementation thereof. Contrary to recent high-quality research that has demonstrated how brief stimuli can change opinions about marginalized out-groups (Adida et al. 2018, Simonovits et al. 2018), our findings provide a counterexample to the power of this paradigm. More generally, like Kuziemko et al. (2015), we provide evidence of the rigidity of preferences regarding redistribution even in the face of a seemingly powerful treatment designed to facilitate perspective-taking with the poor.

This study makes several contributions to the literature. First, we contribute to the literature on perspective-taking by investigating the effect of perspective-taking with the poor, a large and relevant social group that has not previously been investigated in this framework. We advance the literature by investigating the effect of perspective-taking on policy attitudes. We continue the methodological exploration into implementing perspective-taking exercises in online surveys. Second, we contribute to the literature on welfare attitudes by running a rigorous large-scale experiment in a field dominated by observational data (but see Sands (2017)) and by linking the deservingness heuristics with policy attitudes, while most of the literature stops at more proximate outcomes. Third, multiple recent studies explore the effects of dispositional 
empathy on welfare attitudes and polarization (Feldman et al. 2019; Simas et al. 2020), but these individual differences are likely to be stable over time. Instead, we focus on empathic concern, which is a psychological process experienced by all healthy humans regularly (albeit with different frequency and towards different groups).

\section{Theory}

\section{What determines attitudes towards redistribution?}

For decades, citizens and scholars alike have been preoccupied with finding the determinants of social welfare attitudes (Campbell et al. 1960). This is hardly surprising given that economic redistribution is a major part of the function of advanced democracies. Most citizens are directly affected by this, first as taxpayers and, later in life, as recipients of various welfare benefits from health care to old-age pension. Welfare attitudes have been at the epicenter of debates about the extent to which citizens' policy positions are self-serving. Some accounts argue that selfinterest is at best a very weak predictor of attitudes (Bartels 2005; Fong 2001); others find strong associations by looking at temporal effects of external shocks (Margalit 2013) or by broadening the definition of self-interest (Weeden and Kurzban 2017). However, it is hardly debatable that self-interest leaves plenty of room for other factors to influence these attitudes. Cultural norms and historical trajectories (Alesina and Giuliano 2011), party cues (Bartels 2016), ethnic and racial attitudes (Harell et al. 2016) and microenvironment (Sands 2017) all shape attitudes towards redistribution.

More recently, increasing attention has been paid to the psychological foundations of forming welfare attitudes: How does our mind make the decision to support or oppose (more) welfare spending? To answer this question, it is helpful to consider the experiences of our ancestors. Although social welfare may seem as a modern invention, humans have maintained an intricate system of resource sharing through much of our evolutionary history (Gurven and Jaeggi 2015). Helping the needy has been an important strategy to accumulate favors necessary to increase the chances of survival in times of personal misfortune. However, maintaining these cooperative relationships and avoiding exploitation by free-riders require a sophisticated psychological machinery (Cosmides and Tooby 2016). Human sharing decisions are driven by the deservingness heuristic. Unlucky individuals elicit feelings of compassion and receive help; individuals who are 
responsible for their own misery elicit feelings of anger or disgust and receive no help (Petersen 2012).

A growing literature argues that powerful intuitions associated with this ancestral cognitive calculus feed into modern-day decisions on welfare attitudes across cultures (Sznycer et al. 2017). Indeed, political scientists building on these insights have demonstrated that news stories containing negative deservingness cues have long-lasting effects on welfare attitudes in both the US and Denmark (Laustsen et al. 2017). Despite large cultural differences between these two countries and a substantial gap in baseline support for welfare, Americans and Danes agree on which needy individuals deserve help and which do not (Aarøe and Petersen 2014). The ancestral logic of resource sharing also helps to explain large and cross-cultural differences between the support for various forms of welfare benefits. Most people consider poor health to be less of a consequence of individual decisions, tag ill people as deserving and, therefore, strongly support public health care. Meanwhile, many people associate unemployment with laziness and tag the unemployed as undeserving, leading to considerably lower public support for unemployment benefits (Jensen and Petersen 2017). There is evidence that stories with epistemic frames employing deservingness cues - accounts focusing on a single needy individual and containing information about whether they are unlucky or lazy - are particularly persuasive and very likely to be transmitted in interpersonal communication (Aarøe and Petersen 2018). This is particularly important for our endeavor as exploiting strong reactions to vivid and intimate details of a single individual's experiences has been at the core of the perspectivetaking literature, too. We consider this area next.

\section{Empathy and perspective-taking experiments}

People are prone to automatically and involuntarily take the perspective of other individuals in their environment (Stotland 1969). This should not surprise anyone who ever winced in pain witnessing a friend (or a cartoon character) smashing their finger with a hammer. While this comes naturally to most of us, it requires complex mental computations, including the cognitive ability to predict the internal states of others - "this person feels pain" - and the

affective response of experiencing appropriate emotions - "I feel the pain" (Baron-Cohen and Wheelwright 2004). We refer to this psychological process as empathy. Empathy is crucial for 
navigating social interactions (Baron-Cohen et al. 1985) and plays a significant role in moral reasoning (Kohlberg 1976).

Naturally, empathy does not turn humans into unconditional altruists. While empathy is an important prerequisite of altruism, it is inhibited in situations of conflict (Batson 1991). Indeed, there is growing evidence that people routinely regulate their empathic response (Decety 2011; Feldman et al. 2019). Yet, given the right conditions, such as a needy and deserving individual, empathy facilitates strong feelings of compassion, defined as an emotion "that arises in witnessing another's suffering and that motivates a subsequent desire to help" (Goetz et al. 2010, 351) ${ }^{1}$

Social psychologists have long realized that empathy could be triggered in perspectivetaking experiments seeking to reduce prejudice. Typically, in lab-based studies, participants were asked to imagine themselves in the shoes of a disadvantaged individual. Early studies focused on the interpersonal relationship between participant and target individual and found that perspective-taking often led to an improvement in these relationships (Batson et al. 1997) $2^{2}$ Accordingly, a perspective-taking exercise contributes to pro-social emotions and frequently induces a helping behavior towards the target individual. Galinsky and Moskowitz (2000) have pushed this argument further by demonstrating that these beneficial effects do not stop at the individual and could spill over to stereotypes about the target's group. According to their argument, perspective-taking creates a "self-other overlap" thereby decreasing negative stereotyping and increasing the association of positive traits with the target out-group.

These findings have propelled more recent studies to employ perspective-taking to improve attitudes towards disadvantaged groups outside the laboratory. Broockman and Kalla (2016) demonstrated experimentally that canvassers could induce a large and long-lasting reduction in transphobia by asking people to recall an event when they were negatively judged for being

\footnotetext{
${ }^{1}$ Note that classic works in the perspective-taking literature (e.g. Batson et al. 1997) define empathy analogous to what we call compassion (for a discussion see Goetz et al. 2010). We find it more fruitful to define empathy broadly, as feeling others' feelings, which may include compassion, but also other emotions not associated with help like anger or sadness. We reserve compassion for feelings inducing a motivation to help.

${ }^{2}$ Interestingly, the first famous perspective-taking study relied on a heavy dose of deservingness cues upon describing their target individual, Katie Banks, who "was desperately trying to take care of her surviving younger brother and sister while she finished her last year of college ... [after her] parents and a sister had recently been killed in an automobile crash" (Batson et al. 1997, 753)
} 
different and then to find links between this personal experience and the every-day experiences of trans people. Simonovits et al. (2018) facilitated perspective-taking by implementing a roleplaying game with realistic scenarios from a Roma adolescent's life in an online experiment in Hungary. This intervention reduced anti-Roma prejudice and decreased vote intention for the racist far-right party, Jobbik. Finally, in a study most similar to previous lab studies and our own effort, Adida et al. (2018) asked online participants to write short essays taking the perspective of a Syrian refugee. They found that this minimalist, non-intrusive intervention increased the likelihood of writing a letter in support of Syrian refugees to the president of the USA, but, interestingly, did not increase support for admitting refugees to the US.

\section{Perspective-taking with the poor}

In the UK, the first Cameron government's Chancellor, George Osborne - the person responsible for cutting welfare benefits - received harsh criticism for his "lack of empathy with the poor". The head of the UKs largest provider of food banks proclaimed that Osborne should "try and put [himself] in other peoples shoes" to get a deeper understanding of the causes of poverty (Hasan 2012). Could perspective-taking with the poor really influence preferences for welfare assistance?

To the best of our knowledge, it has never been investigated whether perspective-taking with the poor has a causal effect on welfare attitudes. However, there is evidence that individual differences in empathy play an important role in forming social welfare attitudes. Feldman and Steenbergen $(2002,659)$ noted that empathy correlates with humanitarianism, "the belief that people have responsibilities toward their fellow human beings and should come to the assistance of others in need", which, in turn, is an important underlying value in welfare attitudes (Hansen 2019). More recently, Gross and Wronski (2019) showed that people with higher empathic ability (as measured with the "Reading the Mind in the Eyes test) donate slightly more when exposed to a story about a deserving homeless individual. Focusing on individual differences in empathic ability, Feldman et al. (2019) showed that more empathetic individuals support more help for needy individuals but warned that the effect of empathy on social welfare attitudes is conditional on people's beliefs in individualism. Among those who strongly believe that people can and should get ahead on their own, higher empathy yields higher support for 
(private) charitable assistance; among those who do not share these views, high empathy yields high support for social welfare. Finally, in Section A of the Online Appendix (OA), we report an original quantitative analysis relying on representative survey data of almost 2,000 Americans from the 2008-9 ANES Panel Study. Results show robust correlations between multiple measures of social welfare attitudes and a psychometrically validated multidimensional measure of individual-level differences in empathy.

\section{Hypotheses}

Grounded in these theoretical works, Figure 1 offers a schematic representation of the psychological process leading from the perspective-taking exercise to possible changes in attitudes towards redistribution. Importantly, Figure 1 marks the main relationships based on extant literature but does not exclude that a relationship may exist between concepts not connected by arrows, nor that perspective-taking may influence support for redistribution through other unique paths not marked here. This schematic model guided our variable selection and offers a good conceptual overview structuring our hypotheses and results. We outlined our expectations in our pre-analysis plan, which was pre-registered at the e-gap website under no. 20190129AB.

Figure 1: Schematic representation of the psychological process linking perspective-taking to support for redistribution

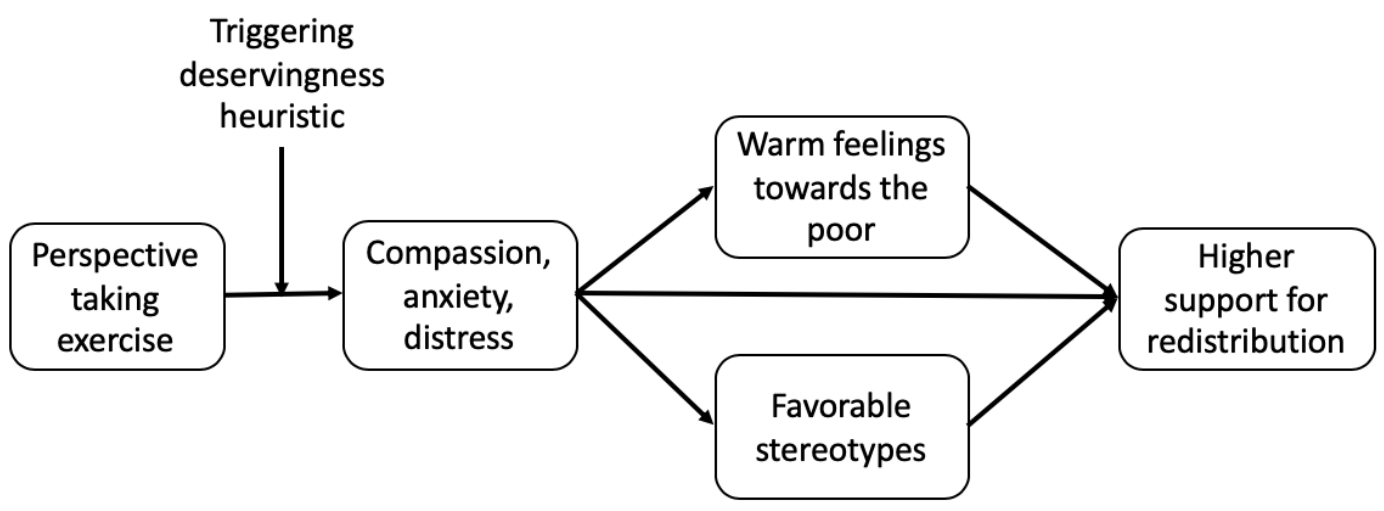

First, we expect that participants' emphatic reactions propel them to experience emotions 
appropriate to the situation of the target individual, most frequently compassion and personal distress (Batson et al. 1997). Combing this insight with consistent findings that deserving individuals elicit feelings of compassion (Petersen 2012), we predict that participants in the treatment group will experience more help-inducing emotions (compassion, anxiety, and distress) compared to the control group (H1).

Second, we expect these emotions to spill over to group-specific attitudes. Again, in line with a large literature on perspective-taking (Galinsky and Moskowitz 2000; Dovidio et al. 2004; Vescio et al. 2003), we believe that by considering the experiences of a poor individual, participants in the treatment group will rate poor people higher on thermometer ratings. More specifically, we also expect positive changes in the stereotypes most relevant for social welfare attitudes: whether poor people are in general competent or incompetent, whether they are making an effort to change their situation or not, and finally, whether a lack of effort or circumstances beyond their control are to blame for their poverty. Thus, we posit that participants in the treatment group will express warmer feelings (H2a) and decreased stereotyping (H2b) towards the poor compared to control subjects.

Finally, and most importantly, we predict that compassionate emotional reactions along with the positive changes in group-specific attitudes will feed into a positive change in support for welfare assistance. Previous research has demonstrated that episodic frames - i.e. a specific story depicting a deserving individual - increase support for a social welfare program more than thematic frames - laying out the arguments in the abstract (Aarøe and Petersen 2018). Combined with the firm evidence that instructions for perspective-taking magnify the emotional impact of others' experience compared to mere observing (Batson et al. 1997), it is reasonable to expect that participants in the treatment group will exhibit higher support for redistributive policies. Thus, we predict that perspective-taking with people in poverty increases support for redistributive policies (Н3).

It is important to highlight two caveats regarding these hypotheses. First, our conceptual framework in Figure 1 implies additional causal relationships that we cannot test using our experiment. For instance, while we can test whether stereotypes about the poor are correlated with support for redistribution with no experimental manipulation of stereotypes, we cannot test whether this relationship is causal. Consequently, we seek to estimate the total effect of 
perspective-taking and shy away from partitioning it into direct and indirect effects. Second, for simplicity, our framework omits possible moderators of the impact of perspective-taking. For instance, there could be differences in the effect of perspective-taking across groups defined by partisanship, gender, or race. Indeed, we pre-registered a prediction proposing a larger treatment effect among more affluent respondents. Our primary focus here is to estimate the average effect of perspective-taking, and we will return to the issue of heterogeneity below.

\section{Data and methods 3}

\section{Experimental procedure}

We use a between-subjects design in which participants are asked to write either about a movie they recently saw (control group) or about a fictional person described in a vignette (treatment group). The vignette depicts a single parent of two who has been a victim of a workplace accident and laid off from work. We match the gender of the target with the gender of the participant to make it easier to imagine their situation. We used white-sounding names as we thought that priming a connection between race and poverty might undermine our mechanism to provoke empathy. The female version of the vignette read:

Kate is 35 years old and she has lived alone with her son Tim and daughter Lily since her ex-husband left her a few years ago. Kate always had a regular job, but she has recently been the victim of a serious work-related injury and was subsequently laid off. She is very motivated to get back to work again but her injury and the anxiety she suffers from make it very difficult for her to find a job. Despite receiving some assistance from the government, Kate struggles to cover daily expenses such as food, bills, and medication and simply does not have enough money to pay her ever-increasing rents. Her landlord now said that they need to move out at the end of the month unless she pays the two months rent she owes. Kate is often worried about the future of her family and blames herself for not being able to provide for her children the life and opportunities they deserve.

\footnotetext{
${ }^{3}$ Our pre-registered pre-analysis plan and all materials necessary for reproducing and replicating our analysis are deposited at https://osf.io/fmjph/.
} 
Participants are first asked to imagine "a day in the life of this individual as if you were that person, looking at the world through his/her eyes and walking through the world in his/her shoes" (Galinsky and Moskowitz 2000, 711). Then they receive three essay-writing prompts asking to explain "how [they] would feel if [they] were in this situation", "what ... [they] would be most stressed or anxious about in this situation" and "what [they] would tell [their] children if they said that it was unfair that their life is so much harder than their friends' at school".

Previous research has demonstrated that similar essay-writing tasks are effective tools to facilitate perspective-taking both in laboratory and online environments (Adida et al. 2018, Batson et al.|1997; Galinsky and Moskowitz 2000). Following the essay-writing task, participants received a brief (approximately 2-minute) task unrelated to the experiment as a distractor and proceeded to answer the outcome measures afterwards.

\section{Participants}

We recruited 3,431 US citizens (mean age 45, 51\% female, $72 \%$ white) through Lucid, a large marketplace for online survey panels (Coppock and Mcclellan|2018). Lucid is an attractive alternative to more established convenience samples (e.g. MTurk) for two reasons. First, it applies quota sampling, which means that the marginal distribution of various demographic characteristics (age, gender, education, race, and region) mirrors population distributions. Second, it has a much larger and thus much less experienced subject pool than most alternatives.

We report summary statistics for the sample in Table OA4 in the online appendix. Our sample is diverse in terms of age, gender, race, and education but leans slightly towards the Democrats. The table also demonstrates that the randomization procedure - which included subjective income as a blocking factor - led to experimental groups that are similar with respect to these demographic characteristics.

\section{Dependent measures and analysis}

To test H1, we asked a series of questions tapping the general emotional state of participants. Specifically, our battery included items pertaining to compassion, anxiety and being upset. We added being disgusted, angry and bored as decoy items. To test H2a, we used a standard feeling thermometer measuring general affect towards poor people along with a set of other groups (e.g. 
old people, African Americans) deployed as placebos. To test H2b, we asked respondents a set of questions probing their stereotypes about the poor (making an effort, being incompetent). Section $\mathrm{B}$ in the OA describes all question wordings.

Our main outcome - testing H3 - is support for redistributive policies. It is based on a comprehensive battery of 10 items based on and extending established measures in the literature (Broockman and Kalla 2016; Brown-Iannuzzi et al. 2015). The items span several fundamental issues of social welfare from health care, through income tax, to universal basic income (see Table 1). Our items focus primarily on policies concerning redistribution to needy individuals (as opposed to taxing the rich), which are most influenced by other-oriented concerns (Cavaillé and Trump 2015). Therefore, these items let us investigate whether a perspective-taking exercise is a viable tool to increase support for redistributive policies.

Table 1: Overview of the ten policies constituting our support for redistribution index

\begin{tabular}{|c|c|}
\hline Label & Question wording \\
\hline Aid to poor & Federal spending on aid to poor people should be cut. \\
\hline Income tax & $\begin{array}{l}\text { The federal income tax should be abolished even if this means the } \\
\text { poor pay more in taxes than the rich. }\end{array}$ \\
\hline Public education & $\begin{array}{l}\text { The government should play no role in paying for families' } \\
\text { education expenses. }\end{array}$ \\
\hline Public services for poor & $\begin{array}{l}\text { Public services for low income individuals should be cut in order } \\
\text { to cut federal income taxes for people who make more than } \$ 200,000 \text {. }\end{array}$ \\
\hline Public medicare for poor & $\begin{array}{l}\text { The federal government should pay for all necessary medical care } \\
\text { for all Americans living on very little income. }\end{array}$ \\
\hline Public higher ed for poor & $\begin{array}{l}\text { The federal government should pay for the college education for } \\
\text { students coming from low income families. }\end{array}$ \\
\hline Affordable housing for poor & $\begin{array}{l}\text { The federal government should provide affordable housing for } \\
\text { families in need. }\end{array}$ \\
\hline Wealth tax & The wealthy should be taxed at a higher rate than the middle class. \\
\hline Public medicare & $\begin{array}{l}\text { The government should not pay for individuals' health care. Those } \\
\text { who cannot afford health care themselves should turn to their } \\
\text { families and private charity for help. }\end{array}$ \\
\hline Universal basic income & $\begin{array}{l}\text { The government should provide every American a universal basic } \\
\text { income amounting to } \$ 1,000 \text { a month, which would be paid for by } \\
\text { raising taxes on individuals earning more than } \$ 150,000 \text { a year. }\end{array}$ \\
\hline
\end{tabular}

We follow the perspective taking literature in focusing on group-related attitudes (as opposed to target-related attitudes) in our dependent measures. At the same time, it is important to acknowledge that the connection between the writing task and policy attitudes is indirect. Some of the policies are completely unrelated to the vignette (such as increased taxes on the 
rich), while others target individuals similar to Kate (e.g. affordable housing for poor) without referring to her. The rationale for operationalizing our outcome this way (rather than asking subjects about policies that would directly and explicitly help Kate) was partly our substantive interest in potential effects on general policy preferences and partly a consequence of our design as the control condition did not include references to a deserving individual. We acknowledge that due to this gap, our estimates represent a lower bound in the sense that perspective-taking could possibly lead to opinion change on policies that are more directly related to the person and situation described in the vignette.

Last, while this set of analyses was not declared in the pre-analysis plan, we also constructed measures of emotional engagement based on the essays. We conducted a sentiment analysis relying on the relevant dimensions from the Linguistic Inquiry and Word Count (LIWC) dictionary. Specifically, we expected the treatment essays to score higher on negative emotions (and anxiety, sadness, and anger in particular), money, health, risk, work, and home. Meanwhile, we expected the control essays to score higher on positive emotions, leisure, and seeing.

We estimate the effect of the perspective-taking exercise by comparing the responses of participants across the treatment and the control group. All outcome measures are recoded to a 0-100 scale, therefore coefficient estimates can be interpreted as percentage point change caused by our intervention. The models are simple OLS regressions that include a binary variable for being in the treatment group and adjust for partisan identity, age, having completed higher education, being female, and identifying as white. These covariates were declared in our preanalysis plan. We also include subjective income as a covariate, to account for the blocking in the randomization, even though we did not pre-register this decision. Throughout our analysis, we report unstandardized regression coefficients and two-tailed hypothesis tests. Our estimates should be regarded as intention-to-treat effects; we quantify the effects of being exposed to perspective-taking.

\section{Results}

First, as a post-hoc manipulation check, we analysed essays written by subjects in both groups. We explored whether these tasks were taken seriously and whether the content of the essays written by treated subjects is consistent with our predictions. Calculating the lexical 
diversity of the essays and comparing the most frequent words in the two groups indicate that participants took the essay-writing task seriously and wrote on topic (for details see Section D in the OA).

Figure 2: Sentiment analysis of essays in the treatment and control groups

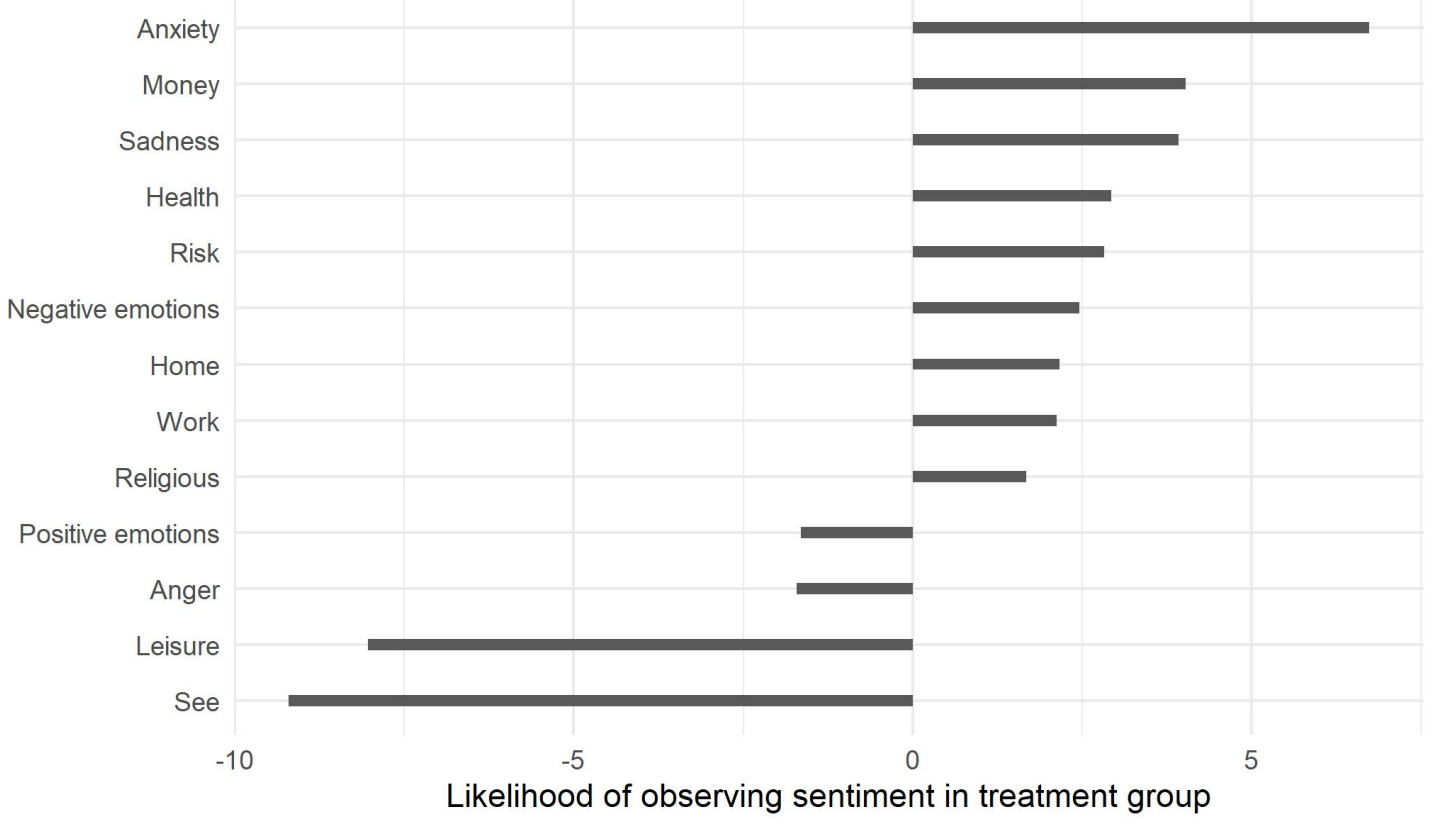

Most importantly, an exploratory sentiment analysis also gives a very strong impression that the perspective-taking exercise triggered the right emotions (see Figure 2). People in the treatment group used almost seven times as many words related to anxiety, four times as many words related to money and sadness, around 3 time as many words related to health and risk, and twice as many words related to negative emotions, home, work, and religion. Meanwhile, participants in the control group used words related to seeing almost ten times more often, words related to leisure eight times more often, and words related to positive emotions almost twice as often. Somewhat surprisingly, we found that participants in the control wrote almost twice as many words related to anger.

Given the apparent success of our experiment in eliciting essays expressing strong emotions with high lexical diversity, we turn to our pre-registered hypotheses. We plot our main causal estimates of interest in Figure 3 Panel A and report detailed regression estimates in Section C of the OA. First, consistent with H1, taking the perspective of a deserving, poor individual had a positive albeit small (5-7\%) effect on help-inducing emotions (compassion, anxiety, and being 
upset). Unexpectedly, similar effects are found for emotions inhibiting help (disgust, anger). Our best post-hoc explanation is that the general emotion questions picked up anger and disgust directed at actors or institutions permitting the suffering of the target. We find a small $(-2 \%)$ negative treatment effect on boredom.

Figure 3: Sample average treatment effects for all pre-registered predictions (Panel A) and predicted support for each redistributive policy in our index split by experimental groups

A

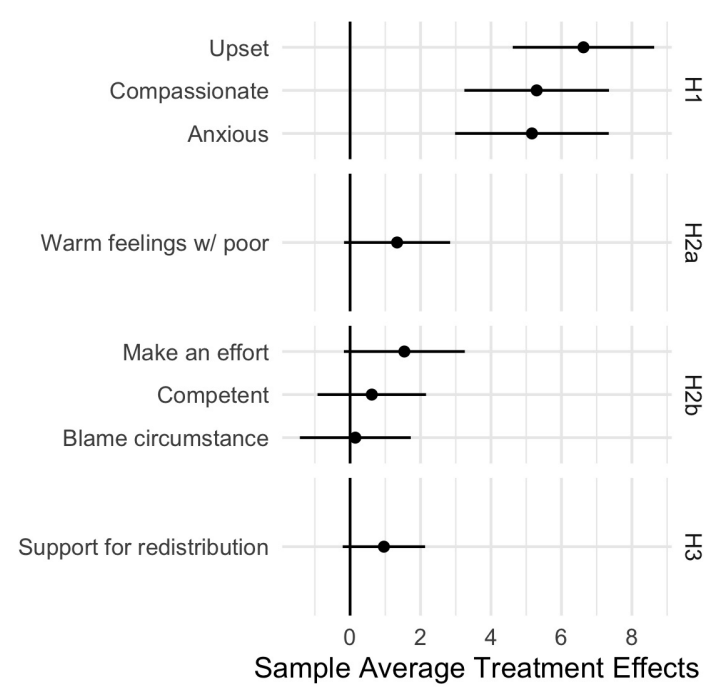

B

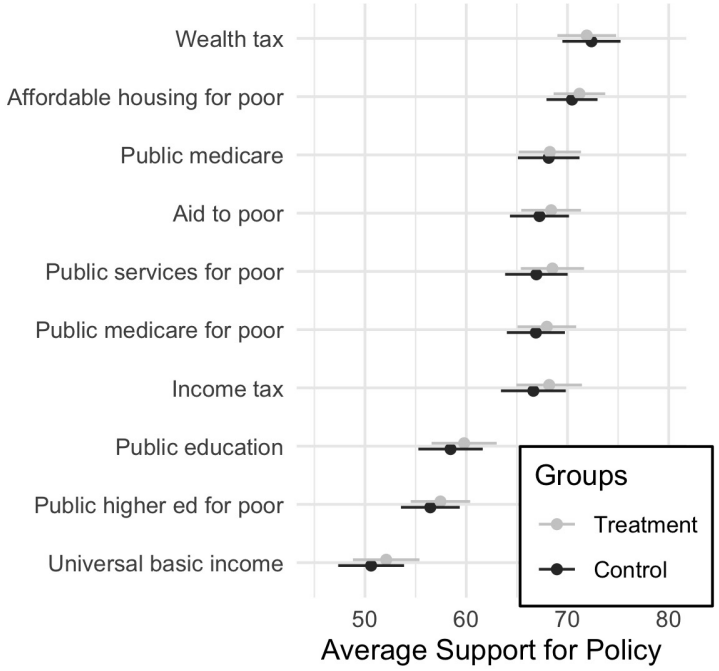

Note: All estimates are based on OLS regressions including an indicator for treatment assignment and adjusting for partisan identity, age, higher education, female, race (white), and subjective income status. Panel A shows unstandardized regression coefficients. Panel B shows predicted values after mean or median centering all covariates. Error bars denote $95 \%$ confidence intervals.

Second, the treatment had a very small (1\%) positive effect on stereotypes about the poor as measured by a feeling thermometer (H2a) and perceptions of making an effort. Both effects are significant only at the 0.1 threshold. The effects on our two other stereotype measures competence and individual responsibility for being poor - were even smaller, and not statistically significant. In short, the data offer only very weak evidence for $\mathrm{H} 2 \mathrm{a}$ and no evidence for $\mathrm{H} 2 \mathrm{~b}$.

Given these findings, it is perhaps not surprising that the perspective-taking exercise had very little effect on our ultimate outcome measure, support for redistribution (H3). Participants' support for welfare was the same whether they wrote an essay about a poor person or about a movie $(\beta=1.0$, se $=0.6, \mathrm{t}=1.6$, n.s. $)$. We conducted a post-hoc equivalence test using as equivalence bounds the smallest effect size of interest (SESOI), i.e. the smallest effect we 
could have detected with $80 \%$ power given our sample size and variance (Lakens 2017). This model suggests that we can reject with high confidence $(\mathrm{t}=1.67, \mathrm{p}<0.05)$ the hypothesis that our treatment effect is larger than the SESOI of 2 points (10\% of a standard deviation in the dependent variable). Put differently, our ultimate treatment effect is statistically equivalent to zero.

Figure 3 Panel B plots the average predicted support for each welfare policy after regressing each item separately on an indicator for treatment assignment and our covariates. Covariates are set to their mean (education, white, age, and female) or median (independent partisan identity and middle income category). It demonstrates that the treatment effect is remarkably similar across all items. It's also worth noting that even the two most popular social welfare policies in our sample (affordable housing and wealth tax) have a mean support of 75 on a 0-100 scale compared to 70 or below for the other issues. Accordingly, it is unlikely that ceiling effects could have suppressed any potential effects.

Next, we investigate whether these zero average effects mask between-group heterogeneity, i.e., some groups - perhaps those who already support redistribution - increase their support, while other groups - perhaps those who oppose redistribution - reduce it. It is not inconceivable that among people who believe that needy individuals are unjustly showered in government support, taking the perspective of such a person backfires. Figure 4 depicts marginal treatment effects among subgroups defined by subjective income, partisan identity, respondent race, and matched respondent-target gender. These post-hoc analyses offer no support for masked heterogeneity. The treatment effects are small, and the $95 \%$ confidence intervals include zero in every subgroup. That said, we lack data on other potentially relevant psychological individual difference measures, such as individualism and humanitarianism. Therefore, we cannot rule out the alternative explanation that the perspective-taking exercise works for some as intended but backfires for others.

Finally, we report a post-hoc investigation of the associations between our proximate variables (affective measures and stereotypes of the poor) and welfare attitudes (see Section F in the OA). Specifically, respondents with more positive stereotypes and warmer feelings about the poor are much more supportive of redistribution. Consistent with the literature on deservingness, stereotypes about the level of effort poor people make is the strongest correlate 
Figure 4: Marginal treatment effects of perspective taking on support for redistribution among subgroups

A

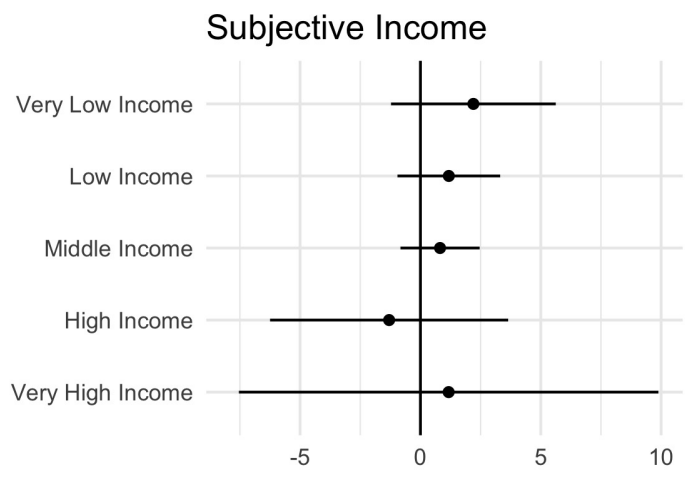

C

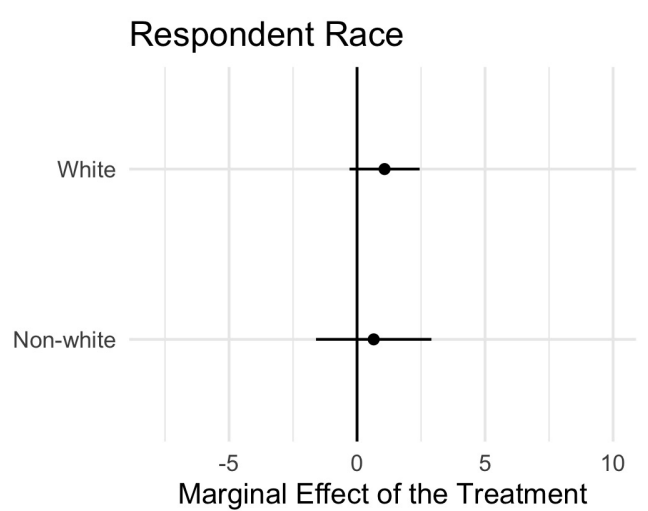

B

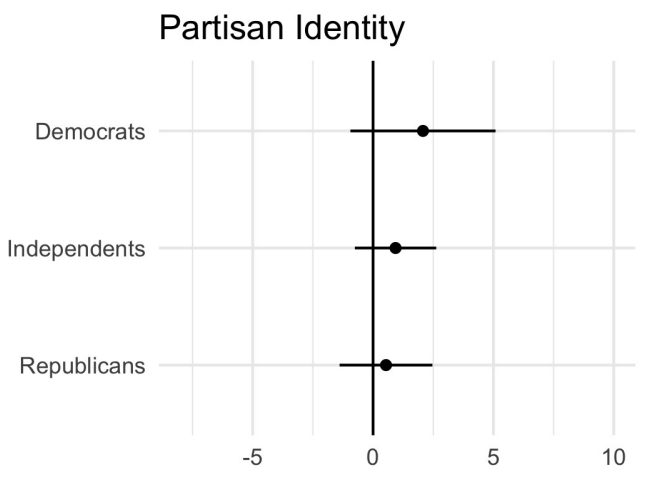

D

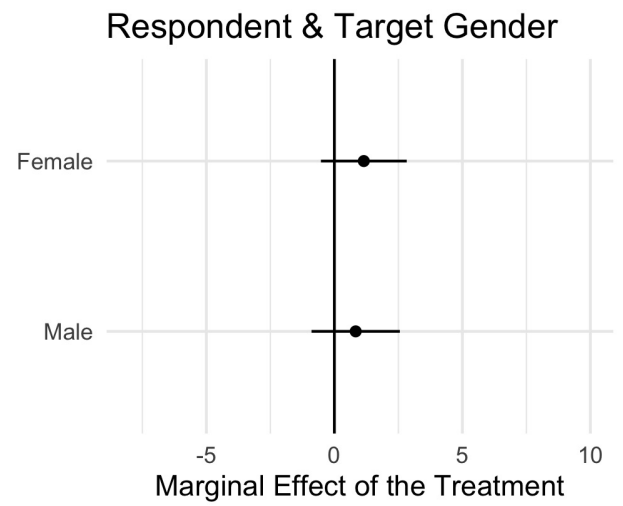

Note: Error bars denote $95 \%$ confidence intervals.

of support for redistribution. Turning our attention to emotions, we restrict our analysis to participants in the treatment group, as we have no particular reason to believe that differences in the control group map onto attitudes towards the poor. Respondents who exhibit high levels of help-inducing emotions after the perspective-taking task have warmer feelings and more positive stereotypes about the poor than respondents who exhibit lower levels of these emotions. At the same time, these associations are weaker than those between stereotypes and policy attitudes. Taken together, the correlations found in our data are generally consistent with the theoretical account depicted in Figure 1. These correlations also hint at the possibility that a perspective-taking task would need to induce a large emotional shock to spill over into policy attitude change. We discuss theoretical accounts consistent with this insight below. 


\section{Discussion}

In this paper, we have tested whether perspective-taking is a viable tool for increasing support for redistribution. Relying on an original, carefully designed, well-powered and preregistered survey experiment fielded to a representative sample of US citizens, we found scant support for our hypothesis. We think that our null results are surprising both given the growing line of research employing perspective-taking to reduce prejudice against various out-groups and because our experimental design relied on a heavy dose of deservingness cues, which in itself, according to previous research, has a large and sometimes long-lasting effect on support for

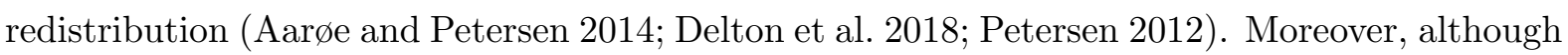
we include a brief distractor task, we measure the outcome a few minutes after exposure to the treatment. Accordingly, this study could detect treatment effects even if they decayed quickly.

To what extent do these null findings advance our understanding of the class of experiments or the substantive target attitude that we study? On the one hand, we think that given the ample evidence that published social science research over-represents successful interventions compared to the universe of all experiments (Franco et al. 2014, 2016), it is imperative that the discipline also considers unsuccessful examples to arrive at a more complete understanding of how a given class of stimuli - such as perspective-taking - works. On the other hand, for a precise interpretation of our findings, we need to consider the possible reasons behind our null findings.

First, it is possible that our treatment had no effect due to features of our design. In the story described in the vignette, poverty results from individual circumstances rather than structural causes, and respondents might have felt a disconnect between the situation we describe and the redistributive policies for which we measure support. In other words, while we find no effect on our general outcome variables, it is possible that we could have identified effects on the intention to help our target and on support for policies more directly benefiting the person described in the vignette. Future research should investigate the generalizability of our findings to outcomes more closely aligned with the perspective-taking task.

Second, our findings may be driven by theoretical mechanisms suppressing perspectivetaking. For instance, it is possible that while subjects felt compassion towards the individual depicted in the vignette, these emotions did not spill over to the broader group of people in need. 
Perhaps participants viewed the target as an "exception" to some deeply held stereotypes about poor people (Brown 1986). Relatedly, Gross (2008) highlights that emotions play an ephemeral role in shaping policy, showing that even though episodic frames evoke strong emotions, they have little effect on policy attitudes (see also Gross and Wronski 2019).

Third, it is possible that our findings differ from earlier studies on perspective-taking because our targeted out-group - i.e. poor people - is different from the out-groups previously studied. In particular, it is noteworthy that most previous studies focus on out-groups that the participant had little risk of joining. In this sense, being poor is a markedly different experience, and consequently, our mind is likely to represent the poor differently. Exploring these differences in more detail could aid our understanding of the surprising results in this study.

Finally, intense exposure to a story about a person in need might have caused emotional reactions that move counter to our hypothesized effect. For instance, exposure to poverty might have provoked anxiety in subjects about their own relative status, suppressing their support for policies helping others (Sands 2017). Similarly, as pointed out by Simas et al. (2020), heightened empathy might exacerbate in-group bias, leading to hostile attitudes towards members of an outgroup. Finally, it is possible that deliberation provided an opportunity for subjects to overcome the grip of deservingness cues and revert to their baseline attitudes. While being engaged in the perspective-taking task, participants' partisan motivations had ample opportunity to hijack the more intuitive responses propelled by deservingness cues. Of course, it is important to note that in our own experiment, we did not vary the availability of deservingness cues independently of perspective-taking, and we can only speculate on why they failed to change support for redistribution. It is an important task for future research to more carefully examine the boundary conditions for the causal effect of deservingness heuristics.

Our findings should remind practitioners, political parties and NGOs that changing attitudes towards redistribution is a tremendous challenge. Even if these actors can convince citizens to take the perspective of poor people, they may fail to shape their attitudes towards them and consequently be ineffective in propelling action. Our study is a reminder that despite a series of promising and highly publicized recent findings, perspective-taking is not a silver bullet; inter-group prejudice is likely to remain a source of social tension. 


\section{Acknowledgements}

We are grateful to Neil Malhotra, Kristina Jessen Hansen, Claire Adida, and Michael Bang Petersen for helpful comments on earlier drafts of this paper.

\section{References}

Aarøe, L. and Petersen, M. B. (2014). Crowding Out Culture: Scandinavians and Americans Agree on Social Welfare in the Face of Deservingness Cues. Journal of Politics, 76(3):684-697.

Aarøe, L. and Petersen, M. B. (2018). Cognitive Biases and Communication Strength in Social Networks: The Case of Episodic Frames. British Journal of Political Science, pages 1-21.

Adida, C. L., Lo, A., and Platas, M. R. (2018). Perspective taking can promote short-term inclusionary behavior toward Syrian refugees. Proceedings of the National Academy of Sciences, 115(38):9521-9526.

Alesina, A. and Giuliano, P. (2011). Preferences for redistribution. In Handbook of Social Economics, pages 93-191. North-Holland.

Baron-Cohen, S., Leslie, A. M., and Frith, U. (1985). Does the autistic child have a theory of mind ? Cognition, 21(1):37-46.

Baron-Cohen, S. and Wheelwright, S. (2004). The Empathy Quotient: An Investigation of Adults with Asperger Syndrome or High Functioning Autism, and Normal Sex Differences. Journal of Autism and Developmental Disorders, 34(2):163-175.

Bartels, L. M. (2005). Homer Gets a Tax Cut: Inequality and Public Policy in the American Mind. Perspectives on Politics, 3(1):15-31.

Bartels, L. M. (2016). Unequal democracy: The political economy of the new gilded age. Princeton University Press, Princeton.

Batson, C. D. (1991). The altruism question: Toward a social- psychological answer. Erlbaum, Hillsdale, NJ. 
Batson, C. D., Early, S., and Salvarani, G. (1997). Perspective taking: Imagining how another feels versus imagining how you would feel. Personality and Social Psychology Bulletin, $23(7): 751-758$.

Bloom, P. (2016). Against Empathy: The Case for Rational Compassion. HarperCollins.

Broockman, D. and Kalla, J. (2016). Durably reducing transphobia: A field experiment on door-to-door canvassing. Science, 352(6282):220-224.

Brown, R. (1986). Social Psychology, the Second Edition. Free Press.

Brown-Iannuzzi, J. L., Lundberg, K. B., Kay, A. C., and Payne, B. K. (2015). Subjective Status Shapes Political Preferences. Psychological Science, 26(1):15-26.

Campbell, A., Converse, P. E., Miller, W. E., and Stokes, D. E. (1960). The American Voter. Midway reprints. University of Chicago Press, Chicago.

Cavaillé, C. and Trump, K.-S. (2015). The Two Facets of Social Policy Preferences. The Journal of Politics, 77(1):146-160.

Coppock, A. and Mcclellan, O. A. (2018). Validating the Demographic, Political, Psychological, and Experimental Results Obtained from a New Source of Online Survey Respondents. Research \& Politics, pages 1-27.

Cosmides, L. and Tooby, J. (2016). Adaptations for Reasoning About Social Exchange. In Buss, D. M., editor, The Handbook of Evolutionary Psychology, pages 625-688. Wiley, Hoboken, NJ.

Covington, M. A. and McFall, J. D. (2010). Cutting the Gordian Knot: The Moving-Average TypeToken Ratio (MATTR). Journal of Quantitative Linguistics, 17(2):94-100.

Davis, M. H. (1980). A Multidimensional Approach to Individual Differences in Empathy. JSAS Catalogue of Selected Documents in Psychology, 10:85.

Decety, J. (2011). Dissecting the Neural Mechanisms Mediating Empathy. Emotion Review, $3(1): 92-108$.

Delton, A. W., Petersen, M. B., DeScioli, P., and Robertson, T. E. (2018). Need, Compassion, and Support for Social Welfare. Political Psychology, 39(4):907-924. 
Dovidio, J. F., Ten Vergert, M., Stewart, T. L., Gaertner, S. L., Johnson, J. D., Esses, V. M., Riek, B. M., and Pearson, A. R. (2004). Perspective and prejudice: Antecedents and mediating mechanisms. Personality and Social Psychology Bulletin, 30(12):1537-1549.

Feldman, S., Huddy, L., Wronski, J., and Lown, P. (2019). The Interplay of Empathy and Individualism in Support for Social Welfare Policies. Political Psychology, in press.

Feldman, S. and Steenbergen, M. R. (2002). The Humanitarian Foundation of Public Support for Social Welfare. American Journal of Political Science, 45(3):658-677.

Fong, C. (2001). Social preferences, self-interest, and the demand for redistribution. Journal of Public Economics, 82(2):225-246.

Franco, A., Malhotra, N., and Simonovits, G. (2014). Publication bias in the social sciences: Unlocking the file drawer. Science, 345(6203):1502-1505.

Franco, A., Malhotra, N., and Simonovits, G. (2016). Underreporting in psychology experiments: Evidence from a study registry. Social Psychological and Personality Science, 7(1):812.

Galinsky, A. D. and Moskowitz, G. B. (2000). Perspective-taking: Decreasing stereotype expression, stereotype accessibility, and in-group favoritism. Journal of Personality and Social Psychology, 78(4):708-724.

Goetz, J. L., Keltner, D., and Simon-Thomas, E. (2010). Compassion: An Evolutionary Analysis and Empirical Review. Psychological Bulletin, 136(3):351-374.

Gross, K. (2008). Framing persuasive appeals: Episodic and thematic framing, emotional response, and policy opinion. Political Psychology, 29(2):169-192.

Gross, K. and Wronski, J. (2019). Helping the Homeless: The Role of Empathy, Race and Deservingness in Motivating Policy Support and Charitable Giving. Political Behavior.

Gurven, M. and Jaeggi, A. V. (2015). Food Sharing. In Scott, R. and Kosslyn, S., editors, Emerging Trends in the Social and Behavioral Sciences, pages 1-12. John Wiley \& Sons, Inc., Hoboken, NJ, USA. 
Hainmueller, J., Mummolo, J., and Xu, Y. (2019). How Much Should We Trust Estimates from Multiplicative Interaction Models? Simple Tools to Improve Empirical Practice. Political Analysis, 27(2):163-192.

Hansen, K. J. (2019). Who Cares If They Need Help? The Deservingness Heuristic, Humanitarianism, and Welfare Opinions. Political Psychology, 40(2):413-430.

Harell, A., Soroka, S., and Iyengar, S. (2016). Race, prejudice and attitudes toward redistribution: A comparative experimental approach. European Journal of Political Research, $55(4): 723-744$

Hasan, M. (2012). Trussell Trust Food Bank Boss Chris Mould Says Ministers Lack Empathy With The Poor.

Jensen, C. and Petersen, M. B. (2017). The Deservingness Heuristic and the Politics of Health Care. American Journal of Political Science, 61(1):68-83.

Kohlberg, L. (1976). Moral stages and moralization: The cognitive-developmental approach. In Lickona, T., editor, Moral development and behavior: Theory, research and social issues, pages 31-53. Holt, Rinehart \& Winston, New York.

Kuziemko, I., Norton, M. I., Saez, E., and Stantcheva, S. (2015). How elastic are preferences for redistribution? evidence from randomized survey experiments. American Economic Review, 105(4):1478-1508.

Lakens, D. (2017). Equivalence Tests: A Practical Primer for t Tests, Correlations, and MetaAnalyses. Social Psychological and Personality Science, 8(4):355-362.

Laustsen, L., Aarøe, L., Hendry, D. J., Hibbing, J. R., Smith, K. B., and Petersen, M. B. (2017). The Deservingness Heuristic in Political Communication: A Comprehensive Test of the Strength of Bias-Congruent Frames and How to Counter Them. Presented at the Annual meeting of the American Political Science Association, San Francisco, USA.

Margalit, Y. (2013). Explaining social policy preferences: Evidence from the great recession. American Political Science Review, 107(1):80-103.

Obama, B. (2006). Transcript of the 2006 Commencement address at Northwestern University. 
Petersen, M. B. (2012). Social Welfare as Small-Scale Help: Evolutionary Psychology and the Deservingness Heuristic. American Journal of Political Science, 56(1):1-16.

Sands, M. L. (2017). Exposure to inequality affects support for redistribution. Proceedings of the National Academy of Sciences of the United States of America, 114(4):663-668.

Simas, E. N., Clifford, S., and Kirkland, J. H. (2020). How empathic concern fuels political polarization. American Political Science Review, 114(1):258-269.

Simonovits, G., Kézdi, G., and Kardos, P. (2018). Seeing the World Through the Other's Eye: An Online Intervention Reducing Ethnic Prejudice. American Political Science Review, 112(1):186-193.

Stotland, E. (1969). Exploratory Investigations of Empathy. In Berkowitz, L., editor, Advances in Experimental Social Psychology, volume 4, pages 271-314. Academic Press, New York.

Sznycer, D., Seal, M. F. L., Sell, A., Lim, J., Porat, R., Shalvi, S., Halperin, E., Cosmides, L., and Tooby, J. (2017). Support for redistribution is shaped by compassion, envy, and self-interest, but not a taste for fairness. Proceedings of the National Academy of Sciences of the United States of America, 114(31):8420-8425.

van Oorschot, W. (2002). Individual motives for contributing to welfare benefits in the Netherlands. Policy and Politics, 30(1):31-46.

Vescio, T. K., Sechrist, G. B., and Paolucci, M. P. (2003). Perspective taking and prejudice reduction: The mediational role of empathy arousal and situational attributions. European Journal of Social Psychology, 33(4):455-472.

Weeden, J. and Kurzban, R. (2017). Self-Interest Is Often a Major Determinant of Issue Attitudes. Political Psychology, 38:67-90. 


\section{Online Appendix}

\section{Contents}

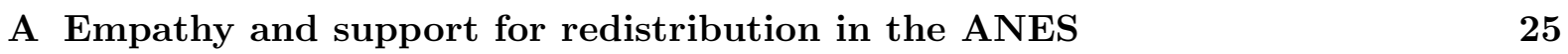

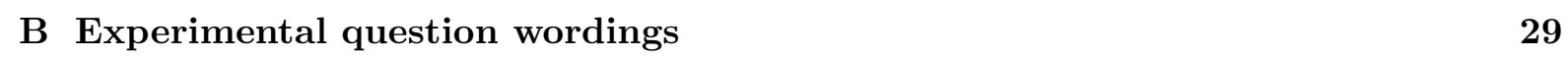

\begin{tabular}{|l|l|}
\hline C Estimates accompanying the analysis of our experiment & 31
\end{tabular}

\begin{tabular}{|l|l|}
\hline D Exploring the essays relying on quantitative text analysis & 36
\end{tabular}

\begin{tabular}{|lll}
\hline E & Pre-registered conditional treatment effects by income & 37
\end{tabular}

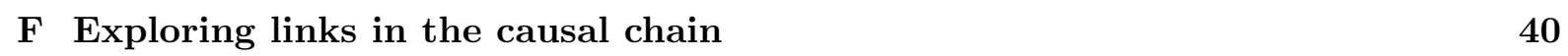




\section{A Empathy and support for redistribution in the ANES}

While our main ambition is to offer an experimental test of the effects of perspective-taking on welfare attitudes, we began our investigation with an exploratory analysis of observational data. Our objective here is to test whether (dispositional) individual differences in empathy are associated with social welfare attitudes in a large, high-quality, representative sample of Americans. Although all healthy humans are capable of empathy, a large body of research documents substantial and stable individual differences with regard to how frequently people employ empathy and how strong their emotional reactions are to the misfortunes of other people (Davis 1980).

We rely on data from the 2008-09 American National Election Study Panel Study 4 The study interviewed a representative sample of US citizens over the internet from January 2008 until September 2009 in 22 waves. We combine data from waves 1 (demographics, party ID), 9, 10, 11, 17, 19 (party ID), 21 (welfare attitudes) and 22 (empathy). For the partisan identity measure observed at multiple waves, we simply average over all observed values. 1,949 respondents with non-missing values on all our variable are included in our analyses.

Our dependent variable - social welfare attitudes - consists of responses to five policy proposals on a diverse range of issues from health insurance, through long term care to economic security. Specifically, respondents were presented two policy positions, and they had to choose whether they agree with one (the liberal), the other (the conservative) or they would position themselves somewhere in between. Table OA1 displays each position. While respondents relied on a 7-point-scale, we recoded all answers to range from 0 to 1 and also formed a welfare attitude index, by averaging across the five items (Cronbach's alpha $=0.8$ ).

\footnotetext{
${ }^{4}$ Our pre-analysis plan mistakenly makes one reference (p3) to a trait empathy scale being included in our own survey. We have omitted this battery because of time constrains from the final version of the survey and therefore rely on ANES data here.
} 
Table OA1: Battery of questions used to measure welfare attitudes in the ANES survey

\begin{tabular}{|c|c|c|}
\hline Issues & Liberal & Conservative \\
\hline $\begin{array}{l}\text { Health } \\
\text { Insurance }\end{array}$ & $\begin{array}{l}\text { Some people feel there should be a government insurance } \\
\text { plan which would cover all medical and hospital expenses } \\
\text { for everyone }\end{array}$ & $\begin{array}{l}\text { Others feel that all medical expenses should be paid by } \\
\text { individuals through private insurance plans like Blue Cross } \\
\text { or other company paid plans }\end{array}$ \\
\hline $\begin{array}{l}\text { Guaranteed } \\
\text { Good } \\
\text { Employment }\end{array}$ & $\begin{array}{l}\text { Some people feel the government in Washington should } \\
\text { see to it that every person has a job and a good standard } \\
\text { of living }\end{array}$ & $\begin{array}{l}\text { Others think the government should just let each person } \\
\text { get ahead on their own }\end{array}$ \\
\hline $\begin{array}{l}\text { Long } \\
\text { Term } \\
\text { Care }\end{array}$ & $\begin{array}{l}\text { Some people feel that there should be a government } \\
\text { insurance plan that would cover nursing home and home } \\
\text { health care expenses for the elderly and disabled. }\end{array}$ & $\begin{array}{l}\text { Others feel that all nursing home and home health expenses } \\
\text { should be paid by individuals through their own savings or } \\
\text { private insurance }\end{array}$ \\
\hline $\begin{array}{l}\text { Guaranteed } \\
\text { Retirement } \\
\text { Income }\end{array}$ & $\begin{array}{l}\text { Other people think that government needs to guarantee an } \\
\text { adequate retirement income to its citizens }\end{array}$ & $\begin{array}{l}\text { Some people think that government should encourage each } \\
\text { person to invest their retirement savings so that they can seek } \\
\text { the highest retirement income, even if its riskier }\end{array}$ \\
\hline $\begin{array}{l}\text { Economic } \\
\text { Security }\end{array}$ & $\begin{array}{l}\text { Some people think that government should play a large role } \\
\text { in helping people feel economically secure }\end{array}$ & $\begin{array}{l}\text { Other people think that if government provides too much } \\
\text { security, people will lose their initiative and capacity to help } \\
\text { themselves }\end{array}$ \\
\hline
\end{tabular}


Our key independent variable is based on three facets of Davis's (1980) classic Interpersonal Reactivity Index (IRI). The IRI measures individual differences in empathy by tapping into 1) people's "ability and proclivity to shift perspectives ... when dealing with other people", that is perspective-taking, 2) "the degree to which the respondent experiences feelings of warmth, compassion and concern for the observed individual", that is empathic concern, and 3) "the individual's own feelings of fear, apprehension and discomfort at witnessing the negative experiences of others", that is personal distress (Davis 1980, 11-12). Each of these facets is measured with seven items. We combine all 21 items into a simple additive index of empathy scaled from 0 to 1 (Cronbach's alpha $=0.74)$.

As demographic covariates, we include in our models age (in years), gender (dummy for females), education (dummy for having a Bachelor's degree or higher), race (dummies for black and Hispanic respondents), income (median split), and partisan identity. We run simple OLS models regressing social welfare attitudes on the IRI and demographic covariates. First, we report raw correlations between the two indices and their constituent facets or items in Table OA2, The bivariate correlations indicate modest, statistically significant associations between dispositional empathy and welfare attitudes.

Table OA2: Descriptive statistics and bivariate correlations between empathy and welfare

\begin{tabular}{clcccccc}
\hline \hline & names & mean & $\mathrm{sd}$ & 1 & 2 & 3 & 4 \\
\hline 1 & Empathy index (IRI) & 0.52 & 0.14 & 1 & 0.78 & 0.45 & 0.68 \\
2 & Empathic concern & 0.67 & 0.19 & 0.78 & 1 & -0.04 & 0.53 \\
3 & Personal distress & 0.36 & 0.18 & 0.45 & -0.04 & 1 & -0.19 \\
4 & Pespective-taking & 0.65 & 0.16 & 0.68 & 0.53 & -0.19 & 1 \\
5 & Welfare index & 0.48 & 0.23 & 0.18 & 0.15 & 0.12 & 0.10 \\
6 & Health Insurance & 0.50 & 0.35 & 0.12 & 0.10 & 0.07 & 0.08 \\
7 & Guaranteed Good Employment & 0.37 & 0.29 & 0.15 & 0.10 & 0.11 & 0.06 \\
8 & Long Term Care & 0.60 & 0.31 & 0.14 & 0.13 & 0.06 & 0.08 \\
9 & Guaranteed Retirement Income & 0.54 & 0.30 & 0.11 & 0.11 & 0.06 & 0.05 \\
10 & Economic Security & 0.38 & 0.30 & 0.16 & 0.09 & 0.14 & 0.08 \\
\hline
\end{tabular}

Next, we turn our attention to our OLS models (see Table OA3). Model 1 shows that there is a meaningful association between individual-level empathy and support for welfare policies; those at the maximum of the empathy scale display a fourteen percentage points higher support for welfare policies than those at the minimum of the scale (95\% CI 0.08, 0.20). This difference corresponds to a $60 \%$ of a standard deviation in the dependent variable. This is notable given 
that we adjust for partisan identity (also associated with empathy) and measure empathy and welfare attitudes a month apart.

Table OA3: Dispositional empathy is positively associated to social welfare attitudes

\begin{tabular}{|c|c|c|c|c|c|c|}
\hline & \multicolumn{6}{|c|}{ Dependent variable: } \\
\hline & $\begin{array}{l}\text { Welf.ind. } \\
\text { (1) }\end{array}$ & $\begin{array}{l}\text { Health Ins. } \\
\qquad(2)\end{array}$ & $\begin{array}{c}\text { Good Empl. } \\
(3) \\
\end{array}$ & $\begin{array}{c}\text { Long-T.Care } \\
(4)\end{array}$ & $\begin{array}{l}\text { Retir.Inc. } \\
(5) \\
\end{array}$ & $\begin{array}{c}\text { Econ.Secur. } \\
(6)\end{array}$ \\
\hline Empathy index & $\begin{array}{c}0.14^{* * *} \\
(0.03)\end{array}$ & $\begin{array}{c}0.21^{* * *} \\
(0.05)\end{array}$ & $\begin{array}{c}0.14^{* * *} \\
(0.05)\end{array}$ & $\begin{array}{l}0.13^{* *} \\
(0.05)\end{array}$ & $\begin{array}{l}0.12^{* *} \\
(0.05)\end{array}$ & $\begin{array}{l}0.11^{* *} \\
(0.05)\end{array}$ \\
\hline Party ID & $\begin{array}{c}-0.34^{* * *} \\
(0.01)\end{array}$ & $\begin{array}{c}-0.35^{* * *} \\
(0.02)\end{array}$ & $\begin{array}{c}-0.31^{* * *} \\
(0.02)\end{array}$ & $\begin{array}{c}-0.34^{* * *} \\
(0.02)\end{array}$ & $\begin{array}{c}-0.20^{* * *} \\
(0.02)\end{array}$ & $\begin{array}{c}-0.52^{* * *} \\
(0.02)\end{array}$ \\
\hline Age & $\begin{array}{c}-0.001^{* * *} \\
(0.0003)\end{array}$ & $\begin{array}{c}-0.002^{* * *} \\
(0.0004)\end{array}$ & $\begin{array}{c}-0.002^{* * *} \\
(0.0004)\end{array}$ & $\begin{array}{l}-0.0002 \\
(0.0005)\end{array}$ & $\begin{array}{c}0.0004 \\
(0.0005)\end{array}$ & $\begin{array}{l}-0.0004 \\
(0.0005)\end{array}$ \\
\hline Hispanic & $\begin{array}{c}0.02 \\
(0.02)\end{array}$ & $\begin{array}{c}0.04 \\
(0.03)\end{array}$ & $\begin{array}{c}0.04 \\
(0.03)\end{array}$ & $\begin{array}{l}-0.04 \\
(0.03)\end{array}$ & $\begin{array}{c}0.03 \\
(0.03)\end{array}$ & $\begin{array}{c}0.02 \\
(0.03)\end{array}$ \\
\hline Black & $\begin{array}{c}0.02 \\
(0.02)\end{array}$ & $\begin{array}{c}0.02 \\
(0.02)\end{array}$ & $\begin{array}{c}0.07^{* * *} \\
(0.02)\end{array}$ & $\begin{array}{l}-0.01 \\
(0.02)\end{array}$ & $\begin{array}{l}-0.04 \\
(0.02)\end{array}$ & $\begin{array}{c}0.03 \\
(0.02)\end{array}$ \\
\hline Higher educated & $\begin{array}{c}-0.004 \\
(0.01)\end{array}$ & $\begin{array}{l}0.002 \\
(0.01)\end{array}$ & $\begin{array}{l}-0.01 \\
(0.01)\end{array}$ & $\begin{array}{l}-0.02 \\
(0.01)\end{array}$ & $\begin{array}{l}-0.02 \\
(0.01)\end{array}$ & $\begin{array}{l}0.03^{* *} \\
(0.01)\end{array}$ \\
\hline Higher income & $\begin{array}{c}-0.04^{* * *} \\
(0.01)\end{array}$ & $\begin{array}{c}-0.04^{* * *} \\
(0.01)\end{array}$ & $\begin{array}{c}-0.04^{* * *} \\
(0.01)\end{array}$ & $\begin{array}{c}-0.05^{* * *} \\
(0.01)\end{array}$ & $\begin{array}{c}-0.04^{* * *} \\
(0.01)\end{array}$ & $\begin{array}{l}-0.02 \\
(0.01)\end{array}$ \\
\hline Female & $\begin{array}{c}0.02 \\
(0.01)\end{array}$ & $\begin{array}{l}-0.01 \\
(0.01)\end{array}$ & $\begin{array}{l}0.03^{* *} \\
(0.01)\end{array}$ & $\begin{array}{c}0.04^{* * *} \\
(0.01)\end{array}$ & $\begin{array}{c}0.02 \\
(0.01)\end{array}$ & $\begin{array}{l}-0.01 \\
(0.01)\end{array}$ \\
\hline Constant & $\begin{array}{c}0.63^{* * *} \\
(0.03)\end{array}$ & $\begin{array}{c}0.55^{* * *} \\
(0.04)\end{array}$ & $\begin{array}{c}0.56^{* * *} \\
(0.04)\end{array}$ & $\begin{array}{c}0.72^{* * *} \\
(0.04)\end{array}$ & $\begin{array}{c}0.58^{* * *} \\
(0.04)\end{array}$ & $\begin{array}{c}0.72^{* * *} \\
(0.04)\end{array}$ \\
\hline Observations & 1,949 & 1,942 & 1,943 & 1,937 & 1,940 & 1,940 \\
\hline Adjusted $\mathrm{R}^{2}$ & 0.34 & 0.22 & 0.21 & 0.18 & 0.07 & 0.32 \\
\hline
\end{tabular}

Models 2-6 disaggregate the welfare index by individual policies. They demonstrate that the association between empathy and government support for the needy is always positive, although it is somewhat larger for health insurance $(\beta=0.21)$ and smaller for the other four policies $(0.11 \leq \beta \mathrm{s} \leq 0.14)$. 


\section{B Experimental question wordings}

\section{Welfare attitudes}

We would like to ask you to read a few statements that have been made recently about taxes and how the federal government supports low-income people. For each statement please indicate the extent to which you agree or disagree. (Response scale: "Strongly agree", "Somewhat agree", "Neither agree nor disagree", "Somewhat disagree", "Strongly disagree"

1. Federal spending on aid to poor people should be cut.

2. The federal income tax should be abolished even if this means the poor pay more in taxes than the rich.

3. The government should play no role in paying for families' education expenses.

4. Public services for low income individuals should be cut in order to cut federal income taxes for people who make more than $\$ 200,000$.

5. The federal government should pay for all necessary medical care for all Americans living on very little income.

6. The federal government should pay for the college education for students coming from low income families.

7. The federal government should provide affordable housing for families in need.

8. The wealthy should be taxed at a higher rate than the middle class.

9. The government should not pay for individuals' health care. Those who cannot afford health care themselves should turn to their families and private charity for help.

10. The government should provide every American a universal basic income amounting to $\$ 1,000$ a month, which would be paid for by raising taxes on individuals earning more than $\$ 150,000$ a year.

\section{Feeling thermometers}

We would like to get your feelings toward some groups of people who have been in the news using something called the feeling thermometer. You can choose any number between 0 and 100. The higher the number, the warmer or more favorable you feel toward the group, the lower the number, the colder or less favorable. You would rate a group at the 50-degree mark if you feel neither warm nor cold toward them. 

1. Elderly
2. People living in poverty
3. Black people
4. Disabled people

\section{Emotions}

We would like you to think for a moment about your emotions. How well each of the following words describe how you feel at the moment? ("A great deal", "A lot", "Somewhat", "A little" or "Not at all").

1. compassionate

2. anxious

3. upset

4. disgusted

5. angry

6. bored

\section{Stereotype measures}

In your opinion, how much effort people living in poverty make to change their lives for the better?

- Making a great deal of effort

- Making a lot of effort

- Making a moderate effort

- Making a little effort

- Making no effort at all

In your opinion, are most people living in poverty competent or incompetent?

- Extremely competent

- Somewhat competent

- Neither competent nor incompetent

- Somewhat incompetent

- Extremely incompetent 
In your opinion, which is more to blame if a person is poor: lack of effort on his or her part or circumstances beyond his or her control?

- Definitely lack of effort

- Probably lack of effort

- Might be lack of effort, might be circumstances beyond control

- Probably circumstances beyond control

- Definitely circumstances beyond control

\section{Estimates accompanying the analysis of our experiment}

First, we report sample characteristics by treatment group.

Table OA4: Sample characteristics by treatment group

\begin{tabular}{lrr}
\hline \hline & Control & Treatment \\
\hline Age & $44.7(17.0)$ & $44.6(16.6)$ \\
Female & $0.51(0.50)$ & $0.52(0.50)$ \\
White & $0.72(0.45)$ & $0.73(0.44)$ \\
Higher ed. & $0.40(0.49)$ & $0.40(0.49)$ \\
Democrat & $0.48(0.50)$ & $0.47(0.50)$ \\
Republican & $0.36(0.48)$ & $0.37(0.48)$ \\
\hline $\mathrm{N}$ & 1781 & 1650 \\
\hline
\end{tabular}

Next, the following four tables provide estimates briefly reported in the main text concerning the sample average treatment effect on 1) perceived emotions, 2) thermometers, 3) stereotypes and 4) redistributive preferences. In every table, the first line called "perspective-taking" reports the estimated difference between the control and treatment groups. All tables report unstandardized regression coefficients with standard errors in parentheses. 
Table OA5: Sample average treatment effects on emotions

\begin{tabular}{|c|c|c|c|c|c|c|}
\hline & \multicolumn{6}{|c|}{ Dependent variable: } \\
\hline & $\begin{array}{c}\text { Compassionate } \\
(1) \\
\end{array}$ & $\begin{array}{c}\text { Anxious } \\
(2) \\
\end{array}$ & $\begin{array}{c}\text { Upset } \\
(3)\end{array}$ & $\begin{array}{c}\text { Disgusted } \\
(4) \\
\end{array}$ & $\begin{array}{c}\text { Angry } \\
(5) \\
\end{array}$ & $\begin{array}{c}\text { Bored } \\
(6) \\
\end{array}$ \\
\hline Perspective taking & $\begin{array}{c}5.3^{* * *} \\
(1.0)\end{array}$ & $\begin{array}{c}5.2^{* * *} \\
(1.1)\end{array}$ & $\begin{array}{c}6.6^{* * *} \\
(1.0)\end{array}$ & $\begin{array}{c}4.8^{* * *} \\
(1.0)\end{array}$ & $\begin{array}{c}4.2^{* * *} \\
(1.0)\end{array}$ & $\begin{array}{c}-2.2^{*} \\
(1.0)\end{array}$ \\
\hline Republican & $\begin{array}{c}2.7 \\
(1.6)\end{array}$ & $\begin{array}{c}0.3 \\
(1.7)\end{array}$ & $\begin{array}{l}-0.3 \\
(1.6)\end{array}$ & $\begin{array}{c}0.8 \\
(1.5)\end{array}$ & $\begin{array}{l}-0.1 \\
(1.5)\end{array}$ & $\begin{array}{l}-1.5 \\
(1.6)\end{array}$ \\
\hline Democrat & $\begin{array}{l}4.9^{* *} \\
(1.6)\end{array}$ & $\begin{array}{c}0.7 \\
(1.7)\end{array}$ & $\begin{array}{c}0.1 \\
(1.5)\end{array}$ & $\begin{array}{c}0.7 \\
(1.4)\end{array}$ & $\begin{array}{c}0.1 \\
(1.5)\end{array}$ & $\begin{array}{l}-0.3 \\
(1.5)\end{array}$ \\
\hline Higher Education & $\begin{array}{c}0.2 \\
(1.1)\end{array}$ & $\begin{array}{l}-0.1 \\
(1.2)\end{array}$ & $\begin{array}{c}1.2 \\
(1.1)\end{array}$ & $\begin{array}{c}1.0 \\
(1.0)\end{array}$ & $\begin{array}{c}1.2 \\
(1.0)\end{array}$ & $\begin{array}{l}-1.6 \\
(1.1)\end{array}$ \\
\hline Low income & $\begin{array}{c}1.1 \\
(1.8)\end{array}$ & $\begin{array}{c}-5.3^{* *} \\
(1.9)\end{array}$ & $\begin{array}{c}-7.7^{* * *} \\
(1.8)\end{array}$ & $\begin{array}{c}-6.1^{* * *} \\
(1.7)\end{array}$ & $\begin{array}{c}-5.3^{* *} \\
(1.7)\end{array}$ & $\begin{array}{c}-5.1^{* *} \\
(1.8)\end{array}$ \\
\hline Middle income & $\begin{array}{c}3.0 \\
(1.7)\end{array}$ & $\begin{array}{c}-10.3^{* * *} \\
(1.8)\end{array}$ & $\begin{array}{c}-11.4^{* * *} \\
(1.7)\end{array}$ & $\begin{array}{c}-7.7^{* * *} \\
(1.6)\end{array}$ & $\begin{array}{c}-8.5^{* * *} \\
(1.6)\end{array}$ & $\begin{array}{c}-7.0^{* * *} \\
(1.7)\end{array}$ \\
\hline High income & $\begin{array}{l}9.0^{* *} \\
(2.7)\end{array}$ & $\begin{array}{l}-7.3^{*} \\
(2.9)\end{array}$ & $\begin{array}{l}-5.5^{*} \\
(2.7)\end{array}$ & $\begin{array}{c}0.1 \\
(2.5)\end{array}$ & $\begin{array}{l}-0.8 \\
(2.6)\end{array}$ & $\begin{array}{l}-2.6 \\
(2.7)\end{array}$ \\
\hline V. high income & $\begin{array}{c}18.6^{* * *} \\
(4.2)\end{array}$ & $\begin{array}{c}2.2 \\
(4.5)\end{array}$ & $\begin{array}{c}12.6^{* *} \\
(4.2)\end{array}$ & $\begin{array}{c}14.8^{* * *} \\
(3.9)\end{array}$ & $\begin{array}{c}11.2^{* *} \\
(3.9)\end{array}$ & $\begin{array}{c}11.0^{* *} \\
(4.2)\end{array}$ \\
\hline White & $\begin{array}{c}0.3 \\
(1.2)\end{array}$ & $\begin{array}{c}-0.001 \\
(1.3)\end{array}$ & $\begin{array}{c}1.6 \\
(1.2)\end{array}$ & $\begin{array}{l}-1.6 \\
(1.1)\end{array}$ & $\begin{array}{c}0.4 \\
(1.2)\end{array}$ & $\begin{array}{c}1.7 \\
(1.2)\end{array}$ \\
\hline Age & $\begin{array}{c}-0.1^{* * *} \\
(0.03)\end{array}$ & $\begin{array}{c}-0.6^{* * *} \\
(0.03)\end{array}$ & $\begin{array}{c}-0.5^{* * *} \\
(0.03)\end{array}$ & $\begin{array}{c}-0.3^{* * *} \\
(0.03)\end{array}$ & $\begin{array}{c}-0.4^{* * *} \\
(0.03)\end{array}$ & $\begin{array}{c}-0.6^{* * *} \\
(0.03)\end{array}$ \\
\hline Female & $\begin{array}{c}6.3^{* * *} \\
(1.1)\end{array}$ & $\begin{array}{l}-1.2 \\
(1.1)\end{array}$ & $\begin{array}{c}-3.5^{* * *} \\
(1.0)\end{array}$ & $\begin{array}{c}-5.3^{* * *} \\
(1.0)\end{array}$ & $\begin{array}{c}-5.6^{* * *} \\
(1.0)\end{array}$ & $\begin{array}{c}-3.0^{* *} \\
(1.0)\end{array}$ \\
\hline Constant & $\begin{array}{c}56.0^{* * *} \\
(2.5)\end{array}$ & $\begin{array}{c}69.8^{* * *} \\
(2.7)\end{array}$ & $\begin{array}{c}50.1^{* * *} \\
(2.5)\end{array}$ & $\begin{array}{c}36.9^{* * *} \\
(2.3)\end{array}$ & $\begin{array}{c}42.5^{* * *} \\
(2.4)\end{array}$ & $\begin{array}{c}61.7^{* * *} \\
(2.5)\end{array}$ \\
\hline Observations & 3,402 & 3,400 & 3,394 & 3,384 & 3,383 & 3,391 \\
\hline Adjusted $\mathrm{R}^{2}$ & 0.03 & 0.1 & 0.1 & 0.1 & 0.1 & 0.1 \\
\hline
\end{tabular}


Table OA6: Sample average treatment effects on group thermometers

\begin{tabular}{|c|c|c|c|c|}
\hline & \multicolumn{4}{|c|}{ Dependent variable: } \\
\hline & $\begin{array}{c}\text { Poor } \\
(1)\end{array}$ & $\begin{array}{c}\text { Black } \\
(2)\end{array}$ & $\begin{array}{c}\text { Disabled } \\
(3)\end{array}$ & $\begin{array}{l}\text { Old } \\
(4)\end{array}$ \\
\hline Perspective taking & $\begin{array}{c}1.3 \\
(0.8)\end{array}$ & $\begin{array}{l}-1.0 \\
(0.8)\end{array}$ & $\begin{array}{l}-0.1 \\
(0.7)\end{array}$ & $\begin{array}{l}-0.1 \\
(0.7)\end{array}$ \\
\hline Republican & $\begin{array}{l}-0.9 \\
(1.2)\end{array}$ & $\begin{array}{c}-3.0^{*} \\
(1.3)\end{array}$ & $\begin{array}{c}1.9 \\
(1.1)\end{array}$ & $\begin{array}{l}2.7^{* *} \\
(1.0)\end{array}$ \\
\hline Democrat & $\begin{array}{c}6.0^{* * *} \\
(1.1)\end{array}$ & $\begin{array}{c}7.6^{* * *} \\
(1.2)\end{array}$ & $\begin{array}{c}3.7^{* * *} \\
(1.0)\end{array}$ & $\begin{array}{l}3.1^{* *} \\
(1.0)\end{array}$ \\
\hline Higher Education & $\begin{array}{c}-0.002 \\
(0.8)\end{array}$ & $\begin{array}{c}-0.01 \\
(0.9)\end{array}$ & $\begin{array}{c}-1.5^{*} \\
(0.7)\end{array}$ & $\begin{array}{l}-1.0 \\
(0.7)\end{array}$ \\
\hline Low income & $\begin{array}{l}-0.6 \\
(1.3)\end{array}$ & $\begin{array}{c}1.2 \\
(1.4)\end{array}$ & $\begin{array}{c}1.3 \\
(1.2)\end{array}$ & $\begin{array}{c}1.6 \\
(1.1)\end{array}$ \\
\hline Middle income & $\begin{array}{c}-3.1^{*} \\
(1.3)\end{array}$ & $\begin{array}{c}1.2 \\
(1.3)\end{array}$ & $\begin{array}{c}0.5 \\
(1.1)\end{array}$ & $\begin{array}{c}0.7 \\
(1.1)\end{array}$ \\
\hline High income & $\begin{array}{c}-4.3^{*} \\
(2.0)\end{array}$ & $\begin{array}{c}0.1 \\
(2.1)\end{array}$ & $\begin{array}{l}-1.3 \\
(1.8)\end{array}$ & $\begin{array}{c}0.7 \\
(1.7)\end{array}$ \\
\hline V. high income & $\begin{array}{l}-1.0 \\
(3.1)\end{array}$ & $\begin{array}{c}4.6 \\
(3.3)\end{array}$ & $\begin{array}{c}3.0 \\
(2.8)\end{array}$ & $\begin{array}{c}4.3 \\
(2.7)\end{array}$ \\
\hline White & $\begin{array}{c}1.7 \\
(0.9)\end{array}$ & $\begin{array}{c}-4.3^{* * *} \\
(1.0)\end{array}$ & $\begin{array}{c}0.9 \\
(0.8)\end{array}$ & $\begin{array}{c}1.1 \\
(0.8)\end{array}$ \\
\hline Age & $\begin{array}{l}0.1^{* * *} \\
(0.02)\end{array}$ & $\begin{array}{c}0.1^{* *} \\
(0.03)\end{array}$ & $\begin{array}{l}0.2^{* * *} \\
(0.02)\end{array}$ & $\begin{array}{l}0.3^{* * *} \\
(0.02)\end{array}$ \\
\hline Female & $\begin{array}{c}4.1^{* * *} \\
(0.8)\end{array}$ & $\begin{array}{c}4.3^{* * *} \\
(0.8)\end{array}$ & $\begin{array}{c}4.8^{* * *} \\
(0.7)\end{array}$ & $\begin{array}{c}4.5^{* * *} \\
(0.7)\end{array}$ \\
\hline Constant & $\begin{array}{c}67.2^{* * *} \\
(1.8)\end{array}$ & $\begin{array}{c}67.0^{* * *} \\
(1.9)\end{array}$ & $\begin{array}{c}66.7^{* * *} \\
(1.7)\end{array}$ & $\begin{array}{c}63.8^{* * *} \\
(1.6)\end{array}$ \\
\hline Observations & 3,423 & 3,423 & 3,423 & 3,423 \\
\hline Adjusted $\mathrm{R}^{2}$ & 0.04 & 0.1 & 0.04 & 0.1 \\
\hline
\end{tabular}


Table OA7: Sample average treatment effects on stereotypes

\begin{tabular}{|c|c|c|c|}
\hline & \multicolumn{3}{|c|}{ Dependent variable: } \\
\hline & $\begin{array}{c}\text { Make an effort } \\
\text { (1) }\end{array}$ & $\begin{array}{c}\text { Competent } \\
(2) \\
\end{array}$ & $\begin{array}{c}\text { Circumstances } \\
(3) \\
\end{array}$ \\
\hline Perspective taking & $\begin{array}{l}1.5 \\
(0.9)\end{array}$ & $\begin{array}{c}0.6 \\
(0.8)\end{array}$ & $\begin{array}{c}0.1 \\
(0.8)\end{array}$ \\
\hline Republican & $\begin{array}{c}-6.0^{* * *} \\
(1.4)\end{array}$ & $\begin{array}{c}2.1 \\
(1.2)\end{array}$ & $\begin{array}{c}-7.1^{* * *} \\
(1.3)\end{array}$ \\
\hline Democrat & $\begin{array}{c}6.0^{* * *} \\
(1.3)\end{array}$ & $\begin{array}{c}5.8^{* * *} \\
(1.2)\end{array}$ & $\begin{array}{l}3.2^{* *} \\
(1.2)\end{array}$ \\
\hline Higher Education & $\begin{array}{l}2.6^{* *} \\
(0.9)\end{array}$ & $\begin{array}{c}1.0 \\
(0.8)\end{array}$ & $\begin{array}{c}0.3 \\
(0.8)\end{array}$ \\
\hline Low income & $\begin{array}{c}-3.9^{*} \\
(1.5)\end{array}$ & $\begin{array}{l}-1.1 \\
(1.4)\end{array}$ & $\begin{array}{c}-4.4^{* *} \\
(1.4)\end{array}$ \\
\hline Middle income & $\begin{array}{c}-7.0^{* * *} \\
(1.4)\end{array}$ & $\begin{array}{c}-3.1^{*} \\
(1.3)\end{array}$ & $\begin{array}{c}-9.4^{* * *} \\
(1.3)\end{array}$ \\
\hline High income & $\begin{array}{l}-0.3 \\
(2.3)\end{array}$ & $\begin{array}{l}-0.1 \\
(2.1)\end{array}$ & $\begin{array}{c}-14.0^{* * *} \\
(2.1)\end{array}$ \\
\hline V. high income & $\begin{array}{c}15.6^{* * *} \\
(3.5)\end{array}$ & $\begin{array}{c}12.9^{* * *} \\
(3.2)\end{array}$ & $\begin{array}{c}-21.2^{* * *} \\
(3.2)\end{array}$ \\
\hline White & $\begin{array}{c}-2.1^{*} \\
(1.0)\end{array}$ & $\begin{array}{l}-0.7 \\
(0.9)\end{array}$ & $\begin{array}{l}2.8^{* *} \\
(1.0)\end{array}$ \\
\hline Age & $\begin{array}{c}-0.2^{* * *} \\
(0.03)\end{array}$ & $\begin{array}{c}-0.1^{* * *} \\
(0.02)\end{array}$ & $\begin{array}{l}0.1^{* * *} \\
(0.03)\end{array}$ \\
\hline Female & $\begin{array}{l}-0.4 \\
(0.9)\end{array}$ & $\begin{array}{c}0.5 \\
(0.8)\end{array}$ & $\begin{array}{c}4.9^{* * *} \\
(0.8)\end{array}$ \\
\hline Constant & $\begin{array}{c}73.2^{* * *} \\
(2.1)\end{array}$ & $\begin{array}{c}66.7^{* * *} \\
(1.9)\end{array}$ & $\begin{array}{c}49.7^{* * *} \\
(1.9)\end{array}$ \\
\hline Observations & 3,423 & 3,423 & 3,421 \\
\hline Adjusted $\mathrm{R}^{2}$ & 0.1 & 0.02 & 0.1 \\
\hline
\end{tabular}


Table OA8: Sample average treatment effects on redistributive preferences

\begin{tabular}{|c|c|}
\hline & Dependent variable: \\
\hline & Redistributive preferences \\
\hline Perspective taking & $\begin{array}{l}1.0 \\
(0.6)\end{array}$ \\
\hline Republican & $\begin{array}{c}-9.9^{* * *} \\
(0.9)\end{array}$ \\
\hline Democrat & $\begin{array}{c}7.6^{* * *} \\
(0.9)\end{array}$ \\
\hline Higher Education & $\begin{array}{c}0.4 \\
(0.6)\end{array}$ \\
\hline Low income & $\begin{array}{c}-4.0^{* * *} \\
(1.0)\end{array}$ \\
\hline Middle income & $\begin{array}{c}-10.1^{* * *} \\
(1.0)\end{array}$ \\
\hline High income & $\begin{array}{c}-15.9^{* * *} \\
(1.6)\end{array}$ \\
\hline V. high income & $\begin{array}{c}-15.6^{* * *} \\
(2.4)\end{array}$ \\
\hline White & $\begin{array}{l}1.8^{*} \\
(0.7)\end{array}$ \\
\hline Age & $\begin{array}{c}0.1^{* *} \\
(0.02)\end{array}$ \\
\hline Female & $\begin{array}{c}3.6^{* * *} \\
(0.6)\end{array}$ \\
\hline Constant & $\begin{array}{c}68.6^{* * *} \\
(1.4)\end{array}$ \\
\hline Observations & 3,423 \\
\hline Adjusted $\mathrm{R}^{2}$ & 0.2 \\
\hline
\end{tabular}




\section{Exploring the essays relying on quantitative text analysis}

Our analyses of the corpora of essays were reassuring. First, we found that most respondents took the task seriously and wrote essays of adequate lengths. Participants in the control conditions wrote five sentences (78 words) on average. Meanwhile, participants in the treatment (receiving three prompts asking for three sentences each) wrote eight sentences (144 words) on average. Relying on Type-Token Ratio as a simple measure of lexical diversity, we find a mean of $\mathrm{m}=0.67(\mathrm{SD}=0.12)$. To put this number in perspective, post-World War II US presidents' inaugural speeches had an identical lexical diversity, when we adjust for mean essay length with the Moving-Average Type-Token Ratio measure (Covington and McFall 2010).

Second, as demonstrated by Figure OA1, an analysis of the most frequent words by conditions reveals that participants in the control indeed wrote about a movie they watched, liked, or would recommend, presumably because they found it good. Meanwhile participants in the treatment group wrote about how they feel and how they would get stressed if they were living the life or were in the same situation as the target in need of help.

Figure OA1: The most frequent word-stems in the control and treatment groups

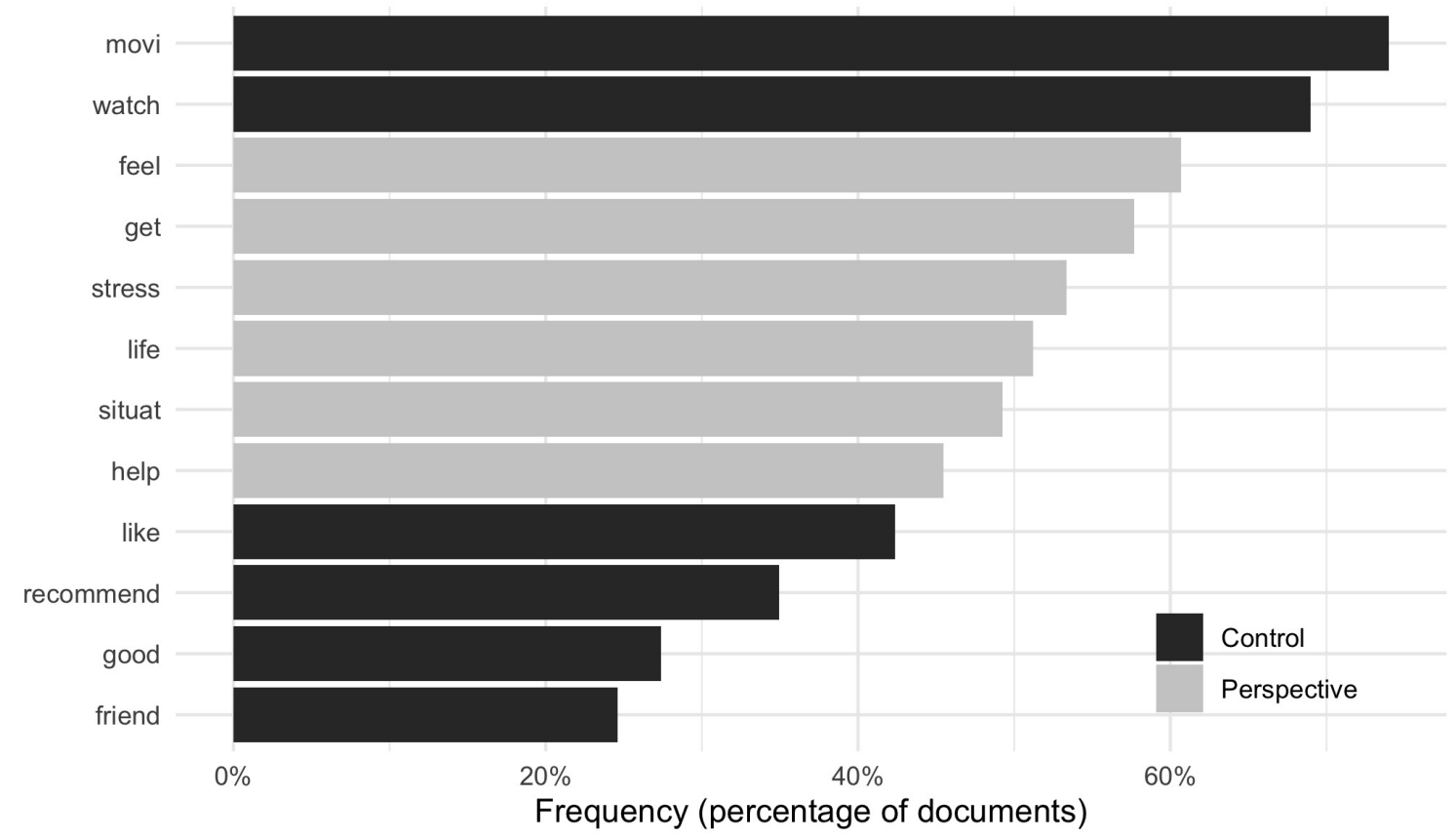




\section{E Pre-registered conditional treatment effects by income}

In our pre-analysis plan, we proposed a theory suggesting that one reason for the relatively low support for redistributive policies in the US is that large parts of society rarely consider the experiences of poor people. Accordingly, we expected that the less likely a participant was to take the perspective of poor people before the experiment, the larger the effects of the treatment would be. Therefore, our treatment may prove to be more effective among people who (1) are more affluent (2) do not consider themselves as poor, and (3) have limited contact with poor people. In the limiting case, we clearly do not expect the treatment to have an impact on people who are experiencing economic hardship themselves. The latter stipulation is analogous to perspective-taking studies targeting prejudice against an ethnic minority by only studying members of the ethnic majority. Given that affluent people traditionally show low support for redistribution, finding a larger treatment effect among them is of particular substantive relevance.

To test these predictions, we measured respondents' (1) self-reported household income, and (2) subjective income status, and (3) an objective measure of affluence in the respondents' place of living. Full question wording and additional data sources for residential affluence are available in the study's pre-analysis plan. Consequently, we estimated the treatment effect of the perspective-taking experiment on support for redistributive policies conditional on each of these three measures. We have no particular theoretical reason to believe that the effect of the perspective-taking exercise changes linearly at a constant rate with income. Therefore, we relax the stringent linear interaction effect assumption and rely primarily on the binning estimator and the kernel estimator in our analyses (Hainmueller et al. 2019).

The binning estimator bins the moderator (our measures of income) into three roughly equally sized groups and estimates the marginal treatment effect independently in each bin. Thereby, we receive an estimate of the average treatment effect for observed low, middle, and high levels of income. The kernel estimator extends this idea by relying on a larger number of bins and applying a kernel reweighting scheme to estimate the smoothed marginal effect across the entire range of the moderator. All models adjust for basic demographic covariates (age, gender, education, race, partisanship), as specified in the pre-analysis plan.

Overall, we find no evidence that the perspective-taking task has increased support for re- 
distributive preferences in any income group. Figure OA2 demonstrates that no matter which income measure or estimation method we rely on, there is no evidence that the marginal treatment effect increases with income. Indeed, if anything, both of our individual level measures (objective household income and subjective income status) hint that more affluent respondents were less like to respond to treatment. This may provide a tentative explanation for our results: While poor people are more likely to take the perspective of another poor individual, they already highly support more redistribution. Meanwhile, more affluent respondents who are further away from the ceiling are seemingly less likely to take the target's perspective and, thus, do not change their redistributive policy preferences. 
Figure OA2: Models exploring marginal effects conditional on income
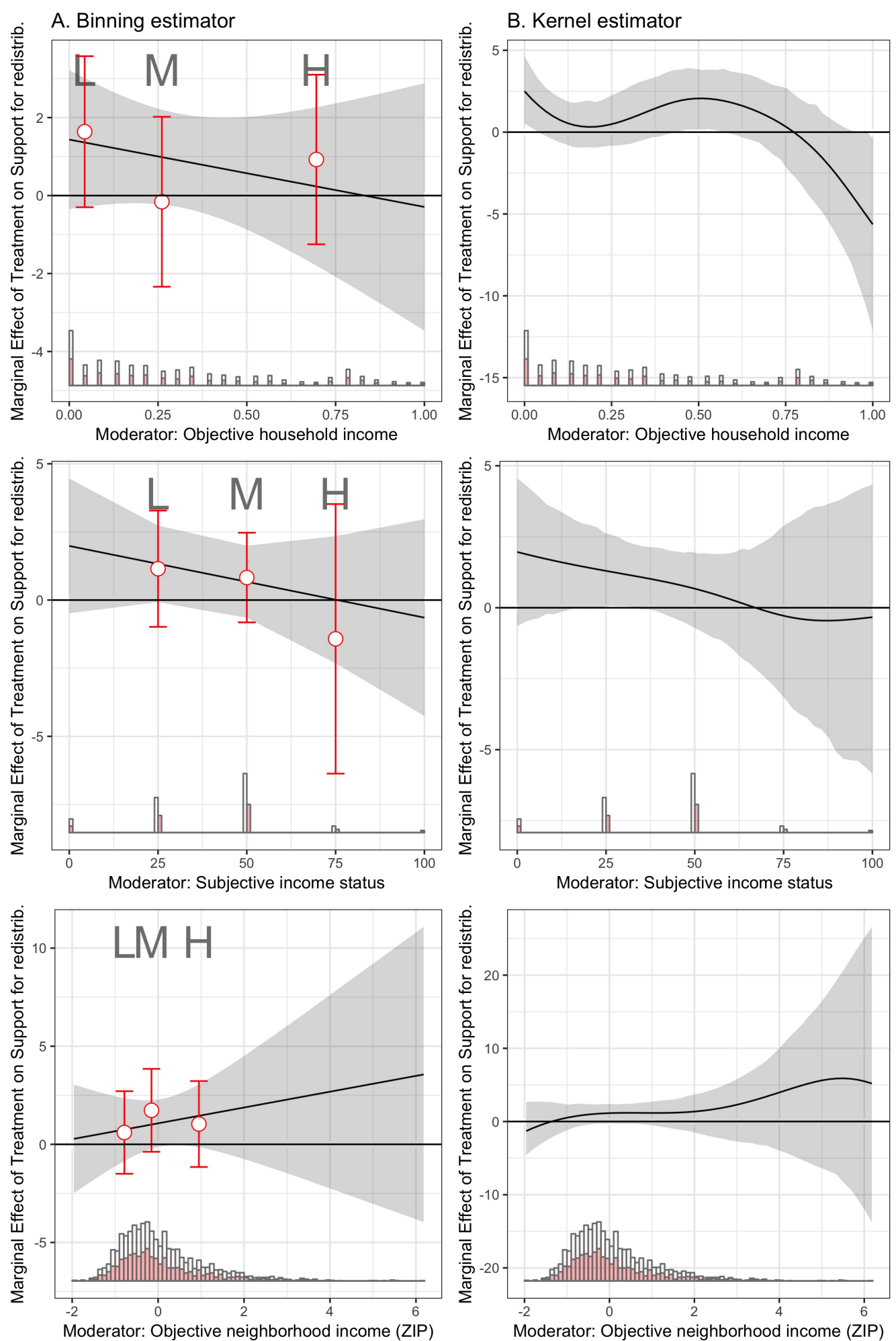


\section{F Exploring links in the causal chain}

The ambition of this section is to explore the links in the causal chain as described in the theory section of our manuscript. Importantly, while we experimentally manipulated perspective taking, we have no leverage to estimate causal effects for the remaining links in the chain. Accordingly, all estimates below are simple correlations and thus should be taken with a grain of salt. That said, our OLS models adjust for demographic variables (age, gender, race, and education) and partisanship, just as the models reported above. All variables - unless noted otherwise - are scaled 0 to 1 . Thus, coefficients could be interpreted as the percentage point difference in the dependent variable between individuals at the minimum and the maximum point of the independent variable, all else equal.

We proceed from welfare attitudes (i.e. the right hand side of the causal chain) backwards. Table OA9 demonstrates the last two links in the causal chain: both favorable stereotypes (poor make an effort, poor are competent, and poverty can be blamed on circumstances and not a lack of effort) and warm feelings toward the poor are positively associated with higher support for redistribution.

Next, we turn to the associations between emotions (compassion, anxiety and being upset) and feelings for the poor. Importantly, here we subset our data to respondents in the treatment group because we have no reason to expect that the emotional response of participants in the control group - writing a short movie review - is relevant for welfare attitudes. We find the predicted positive associations for compassion and anxiety, but not for being upset (see Table OA10.

When it comes to the associations between emotions and stereotypes, we find more mixed results. Table OA11 shows robust relationship between compassion, anxiety and being upset and stereotypes related to making an effort. Meanwhile, Table OA12 shows that the associations between emotions and competence stereotypes are more muted. Finally, Table OA13 the associations between emotions and stereotypes about circumstances are close to 0 (for compassion and anxiety), or negative (for being upset). This latter finding is all the more relevant, given that circumstances (vs lack of effort) showed the strongest correlation with redistributive preferences of the three stereotype measure in our survey. 
Table OA9: The relationship between stereotypes, affect and welfare attitudes

\begin{tabular}{|c|c|c|c|c|}
\hline & \multicolumn{4}{|c|}{ Dependent variable: } \\
\hline & \multicolumn{4}{|c|}{ Redistributive preferences } \\
\hline & $(1)$ & $(2)$ & $(3)$ & $(4)$ \\
\hline Effort & $\begin{array}{c}13.5^{* * *} \\
(1.1)\end{array}$ & & & \\
\hline Competence & & $\begin{array}{c}9.9^{* * *} \\
(1.3)\end{array}$ & & \\
\hline Circumstances & & & $\begin{array}{c}25.7^{* * *} \\
(1.2)\end{array}$ & \\
\hline Affect for poor & & & & $\begin{array}{c}20.7^{* * *} \\
(1.3)\end{array}$ \\
\hline Republican & $\begin{array}{c}-9.1^{* * *} \\
(0.9)\end{array}$ & $\begin{array}{c}-10.1^{* * *} \\
(0.9)\end{array}$ & $\begin{array}{c}-8.1^{* * *} \\
(0.9)\end{array}$ & $\begin{array}{c}-9.7^{* * *} \\
(0.9)\end{array}$ \\
\hline Democrat & $\begin{array}{c}6.7^{* * *} \\
(0.9)\end{array}$ & $\begin{array}{c}7.0^{* * *} \\
(0.9)\end{array}$ & $\begin{array}{c}6.8^{* * *} \\
(0.8)\end{array}$ & $\begin{array}{c}6.3^{* * *} \\
(0.9)\end{array}$ \\
\hline Higher Education & $\begin{array}{c}0.005 \\
(0.6)\end{array}$ & $\begin{array}{c}0.3 \\
(0.6)\end{array}$ & $\begin{array}{c}0.3 \\
(0.6)\end{array}$ & $\begin{array}{c}0.4 \\
(0.6)\end{array}$ \\
\hline Low income & $\begin{array}{c}-3.5^{* * *} \\
(1.0)\end{array}$ & $\begin{array}{c}-3.9^{* * *} \\
(1.0)\end{array}$ & $\begin{array}{c}-2.9^{* *} \\
(1.0)\end{array}$ & $\begin{array}{c}-3.9^{* * *} \\
(1.0)\end{array}$ \\
\hline Middle income & $\begin{array}{c}-9.2^{* * *} \\
(1.0)\end{array}$ & $\begin{array}{c}-9.8^{* * *} \\
(1.0)\end{array}$ & $\begin{array}{c}-7.7^{* * *} \\
(0.9)\end{array}$ & $\begin{array}{c}-9.4^{* * *} \\
(0.9)\end{array}$ \\
\hline High income & $\begin{array}{c}-15.8^{* * *} \\
(1.5)\end{array}$ & $\begin{array}{c}-15.9^{* * *} \\
(1.5)\end{array}$ & $\begin{array}{c}-12.3^{* * *} \\
(1.5)\end{array}$ & $\begin{array}{c}-15.0^{* * *} \\
(1.5)\end{array}$ \\
\hline V. high income & $\begin{array}{c}-17.7^{* * *} \\
(2.4)\end{array}$ & $\begin{array}{c}-16.8^{* * *} \\
(2.4)\end{array}$ & $\begin{array}{c}-10.1^{\text {*** }} \\
(2.3)\end{array}$ & $\begin{array}{c}-15.3^{* * *} \\
(2.3)\end{array}$ \\
\hline White & $\begin{array}{l}2.1^{* *} \\
(0.7)\end{array}$ & $\begin{array}{l}1.8^{* *} \\
(0.7)\end{array}$ & $\begin{array}{c}1.0 \\
(0.7)\end{array}$ & $\begin{array}{l}1.4^{*} \\
(0.7)\end{array}$ \\
\hline Age & $\begin{array}{l}0.1^{* * *} \\
(0.02)\end{array}$ & $\begin{array}{l}0.1^{* * *} \\
(0.02)\end{array}$ & $\begin{array}{c}0.02 \\
(0.02)\end{array}$ & $\begin{array}{l}0.04^{*} \\
(0.02)\end{array}$ \\
\hline Female & $\begin{array}{c}3.6^{* * *} \\
(0.6)\end{array}$ & $\begin{array}{c}3.5^{* * *} \\
(0.6)\end{array}$ & $\begin{array}{c}2.3^{* * *} \\
(0.6)\end{array}$ & $\begin{array}{c}2.7^{* * *} \\
(0.6)\end{array}$ \\
\hline Constant & $\begin{array}{c}59.1^{* * *} \\
(1.6)\end{array}$ & $\begin{array}{c}62.5^{* * *} \\
(1.6)\end{array}$ & $\begin{array}{c}56.3^{* * *} \\
(1.4)\end{array}$ & $\begin{array}{c}55.0^{* * *} \\
(1.6)\end{array}$ \\
\hline Observations & 3,423 & 3,423 & 3,421 & 3,423 \\
\hline Adjusted $\mathrm{R}^{2}$ & 0.3 & 0.2 & 0.3 & 0.3 \\
\hline
\end{tabular}


Table OA10: The relationship between emotions and feelings for the poor

\begin{tabular}{|c|c|c|c|}
\hline & \multicolumn{3}{|c|}{ Dependent variable: } \\
\hline & \multicolumn{3}{|c|}{ Feelings for poor } \\
\hline & $(1)$ & $(2)$ & $(3)$ \\
\hline Compassion & $\begin{array}{c}18.7^{* * *} \\
(1.7)\end{array}$ & & \\
\hline Anxiety & & $\begin{array}{l}5.3^{* *} \\
(1.6)\end{array}$ & \\
\hline Upset & & & $\begin{array}{l}-0.3 \\
(1.7)\end{array}$ \\
\hline Republican & $\begin{array}{l}-0.1 \\
(1.6)\end{array}$ & $\begin{array}{c}0.2 \\
(1.7)\end{array}$ & $\begin{array}{c}0.1 \\
(1.7)\end{array}$ \\
\hline Democrat & $\begin{array}{c}5.2^{* * *} \\
(1.5)\end{array}$ & $\begin{array}{c}5.7^{* * *} \\
(1.6)\end{array}$ & $\begin{array}{c}5.9^{* * *} \\
(1.6)\end{array}$ \\
\hline Higher Education & $\begin{array}{l}-0.3 \\
(1.1)\end{array}$ & $\begin{array}{l}-0.1 \\
(1.1)\end{array}$ & $\begin{array}{c}-0.03 \\
(1.1)\end{array}$ \\
\hline Low income & $\begin{array}{l}-2.0 \\
(1.8)\end{array}$ & $\begin{array}{l}-1.2 \\
(1.9)\end{array}$ & $\begin{array}{l}-1.4 \\
(1.9)\end{array}$ \\
\hline Middle income & $\begin{array}{c}-6.5^{* * *} \\
(1.7)\end{array}$ & $\begin{array}{c}-5.1^{* *} \\
(1.8)\end{array}$ & $\begin{array}{c}-5.5^{* *} \\
(1.8)\end{array}$ \\
\hline High income & $\begin{array}{c}-7.6^{* *} \\
(2.7)\end{array}$ & $\begin{array}{l}-4.8 \\
(2.8)\end{array}$ & $\begin{array}{l}-5.0 \\
(2.8)\end{array}$ \\
\hline V. high income & $\begin{array}{l}-2.9 \\
(4.3)\end{array}$ & $\begin{array}{c}2.1 \\
(4.4)\end{array}$ & $\begin{array}{c}2.2 \\
(4.4)\end{array}$ \\
\hline White & $\begin{array}{l}2.5^{*} \\
(1.2)\end{array}$ & $\begin{array}{l}3.5^{* *} \\
(1.3)\end{array}$ & $\begin{array}{l}3.6^{* *} \\
(1.3)\end{array}$ \\
\hline Age & $\begin{array}{c}0.1^{*} \\
(0.03)\end{array}$ & $\begin{array}{c}0.1^{*} \\
(0.04)\end{array}$ & $\begin{array}{c}0.1 \\
(0.04)\end{array}$ \\
\hline Female & $\begin{array}{c}2.0 \\
(1.1)\end{array}$ & $\begin{array}{c}3.7^{* * *} \\
(1.1)\end{array}$ & $\begin{array}{c}3.6^{* * *} \\
(1.1)\end{array}$ \\
\hline Constant & $\begin{array}{c}60.0^{* * *} \\
(2.6)\end{array}$ & $\begin{array}{c}66.3^{* * *} \\
(2.8)\end{array}$ & $\begin{array}{c}70.1^{* * *} \\
(2.7)\end{array}$ \\
\hline Observations & 1,638 & 1,638 & 1,637 \\
\hline Adjusted $\mathrm{R}^{2}$ & 0.1 & 0.04 & 0.03 \\
\hline
\end{tabular}


Table OA11: The relationship between emotions and effort stereotypes

\begin{tabular}{|c|c|c|c|}
\hline & \multicolumn{3}{|c|}{ Dependent variable: } \\
\hline & \multicolumn{3}{|c|}{ Poor makes an effort } \\
\hline & $(1)$ & $(2)$ & $(3)$ \\
\hline Compassion & $\begin{array}{c}17.2^{* * *} \\
(2.1)\end{array}$ & & \\
\hline Anxiety & & $\begin{array}{l}6.0^{* *} \\
(1.9)\end{array}$ & \\
\hline Upset & & & $\begin{array}{c}7.4^{* * *} \\
(2.0)\end{array}$ \\
\hline Republican & $\begin{array}{c}-6.7^{\text {*** }} \\
(1.9)\end{array}$ & $\begin{array}{c}-6.4^{* *} \\
(2.0)\end{array}$ & $\begin{array}{c}-6.4^{* *} \\
(2.0)\end{array}$ \\
\hline Democrat & $\begin{array}{l}5.2^{* *} \\
(1.8)\end{array}$ & $\begin{array}{l}5.7^{* *} \\
(1.9)\end{array}$ & $\begin{array}{l}5.7^{* *} \\
(1.9)\end{array}$ \\
\hline Higher Education & $\begin{array}{l}2.6^{*} \\
(1.3)\end{array}$ & $\begin{array}{l}2.7^{*} \\
(1.3)\end{array}$ & $\begin{array}{c}2.6 \\
(1.3)\end{array}$ \\
\hline Low income & $\begin{array}{l}-2.3 \\
(2.1)\end{array}$ & $\begin{array}{l}-1.4 \\
(2.2)\end{array}$ & $\begin{array}{l}-1.1 \\
(2.2)\end{array}$ \\
\hline Middle income & $\begin{array}{c}-7.2^{* * *} \\
(2.0)\end{array}$ & $\begin{array}{c}-5.8^{* *} \\
(2.1)\end{array}$ & $\begin{array}{c}-5.5^{* *} \\
(2.1)\end{array}$ \\
\hline High income & $\begin{array}{c}2.2 \\
(3.3)\end{array}$ & $\begin{array}{c}5.2 \\
(3.3)\end{array}$ & $\begin{array}{c}4.8 \\
(3.3)\end{array}$ \\
\hline V. high income & $\begin{array}{l}12.5^{*} \\
(5.1)\end{array}$ & $\begin{array}{c}17.1^{* *} \\
(5.2)\end{array}$ & $\begin{array}{c}16.3^{* *} \\
(5.2)\end{array}$ \\
\hline White & $\begin{array}{l}-1.4 \\
(1.5)\end{array}$ & $\begin{array}{l}-0.8 \\
(1.5)\end{array}$ & $\begin{array}{l}-0.8 \\
(1.5)\end{array}$ \\
\hline Age & $\begin{array}{c}-0.2^{* * *} \\
(0.04)\end{array}$ & $\begin{array}{c}-0.2^{* * *} \\
(0.04)\end{array}$ & $\begin{array}{c}-0.2^{* * *} \\
(0.04)\end{array}$ \\
\hline Female & $\begin{array}{l}-1.0 \\
(1.3)\end{array}$ & $\begin{array}{c}0.5 \\
(1.3)\end{array}$ & $\begin{array}{c}0.5 \\
(1.3)\end{array}$ \\
\hline Constant & $\begin{array}{c}63.9^{* * *} \\
(3.2)\end{array}$ & $\begin{array}{c}69.1^{* * *} \\
(3.3)\end{array}$ & $\begin{array}{c}69.1^{* * *} \\
(3.2)\end{array}$ \\
\hline Observations & 1,638 & 1,638 & 1,637 \\
\hline Adjusted $\mathrm{R}^{2}$ & 0.1 & 0.1 & 0.1 \\
\hline
\end{tabular}


Table OA12: The relationship between emotions and competence stereotypes

\begin{tabular}{|c|c|c|c|}
\hline & \multicolumn{3}{|c|}{ Dependent variable: } \\
\hline & \multicolumn{3}{|c|}{ Poor is competent } \\
\hline & $(1)$ & $(2)$ & $(3)$ \\
\hline Compassion & $\begin{array}{c}11.5^{* * *} \\
(1.8)\end{array}$ & & \\
\hline Anxiety & & $\begin{array}{c}2.3 \\
(1.7)\end{array}$ & \\
\hline Upset & & & $\begin{array}{l}5.7^{* *} \\
(1.8)\end{array}$ \\
\hline Republican & $\begin{array}{c}2.1 \\
(1.7)\end{array}$ & $\begin{array}{c}2.3 \\
(1.7)\end{array}$ & $\begin{array}{c}2.3 \\
(1.7)\end{array}$ \\
\hline Democrat & $\begin{array}{c}5.5^{* * *} \\
(1.7)\end{array}$ & $\begin{array}{c}5.8^{* * *} \\
(1.7)\end{array}$ & $\begin{array}{c}5.9^{* * *} \\
(1.7)\end{array}$ \\
\hline Higher Education & $\begin{array}{c}0.6 \\
(1.2)\end{array}$ & $\begin{array}{c}0.7 \\
(1.2)\end{array}$ & $\begin{array}{c}0.5 \\
(1.2)\end{array}$ \\
\hline Low income & $\begin{array}{l}-1.7 \\
(1.9)\end{array}$ & $\begin{array}{l}-1.1 \\
(1.9)\end{array}$ & $\begin{array}{l}-0.9 \\
(1.9)\end{array}$ \\
\hline Middle income & $\begin{array}{c}-4.4^{*} \\
(1.8)\end{array}$ & $\begin{array}{c}-3.7^{*} \\
(1.9)\end{array}$ & $\begin{array}{l}-3.2 \\
(1.9)\end{array}$ \\
\hline High income & $\begin{array}{l}-0.3 \\
(2.9)\end{array}$ & $\begin{array}{c}1.6 \\
(3.0)\end{array}$ & $\begin{array}{c}1.4 \\
(2.9)\end{array}$ \\
\hline V. high income & $\begin{array}{c}12.6^{* *} \\
(4.6)\end{array}$ & $\begin{array}{c}15.7^{* * *} \\
(4.6)\end{array}$ & $\begin{array}{c}15.2^{* * *} \\
(4.6)\end{array}$ \\
\hline White & $\begin{array}{c}1.3 \\
(1.3)\end{array}$ & $\begin{array}{c}1.9 \\
(1.3)\end{array}$ & $\begin{array}{c}1.6 \\
(1.3)\end{array}$ \\
\hline Age & $\begin{array}{l}-0.1^{*} \\
(0.04)\end{array}$ & $\begin{array}{l}-0.1^{*} \\
(0.04)\end{array}$ & $\begin{array}{c}-0.1 \\
(0.04)\end{array}$ \\
\hline Female & $\begin{array}{l}-0.6 \\
(1.1)\end{array}$ & $\begin{array}{c}0.4 \\
(1.1)\end{array}$ & $\begin{array}{c}0.5 \\
(1.1)\end{array}$ \\
\hline Constant & $\begin{array}{c}59.4^{* * *} \\
(2.8)\end{array}$ & $\begin{array}{c}64.1^{* * *} \\
(3.0)\end{array}$ & $\begin{array}{c}62.4^{* * *} \\
(2.8)\end{array}$ \\
\hline Observations & 1,638 & 1,638 & 1,637 \\
\hline Adjusted $\mathrm{R}^{2}$ & 0.05 & 0.03 & 0.03 \\
\hline
\end{tabular}


Table OA13: The relationship between emotions and circumstance stereotypes

\begin{tabular}{|c|c|c|c|}
\hline & \multicolumn{3}{|c|}{ Dependent variable: } \\
\hline & \multicolumn{3}{|c|}{ Poor due to circumstances } \\
\hline & (1) & $(2)$ & $(3)$ \\
\hline Compassion & $\begin{array}{c}0.6 \\
(1.9)\end{array}$ & & \\
\hline Anxiety & & $\begin{array}{l}-2.1 \\
(1.7)\end{array}$ & \\
\hline Upset & & & $\begin{array}{c}-4.1^{*} \\
(1.8)\end{array}$ \\
\hline Republican & $\begin{array}{c}-7.6^{* * *} \\
(1.8)\end{array}$ & $\begin{array}{c}-7.7^{* * *} \\
(1.8)\end{array}$ & $\begin{array}{c}-7.4^{* * *} \\
(1.8)\end{array}$ \\
\hline Democrat & $\begin{array}{l}3.6^{*} \\
(1.7)\end{array}$ & $\begin{array}{l}3.6^{*} \\
(1.7)\end{array}$ & $\begin{array}{l}3.9^{*} \\
(1.7)\end{array}$ \\
\hline Higher Education & $\begin{array}{l}0.04 \\
(1.2)\end{array}$ & $\begin{array}{c}0.2 \\
(1.2)\end{array}$ & $\begin{array}{c}0.2 \\
(1.2)\end{array}$ \\
\hline Low income & $\begin{array}{c}-5.9^{* *} \\
(2.0)\end{array}$ & $\begin{array}{c}-5.9^{* *} \\
(2.0)\end{array}$ & $\begin{array}{c}-6.1^{* *} \\
(2.0)\end{array}$ \\
\hline Middle income & $\begin{array}{c}-10.1^{\text {*** }} \\
(1.9)\end{array}$ & $\begin{array}{c}-10.4^{* * *} \\
(1.9)\end{array}$ & $\begin{array}{c}-10.7^{\text {*** }} \\
(1.9)\end{array}$ \\
\hline High income & $\begin{array}{c}-19.8^{* * *} \\
(3.0)\end{array}$ & $\begin{array}{c}-19.4^{* * *} \\
(3.0)\end{array}$ & $\begin{array}{c}-19.8^{* * *} \\
(3.0)\end{array}$ \\
\hline V. high income & $\begin{array}{c}-28.9^{* * *} \\
(4.7)\end{array}$ & $\begin{array}{c}-28.8^{* * *} \\
(4.6)\end{array}$ & $\begin{array}{c}-28.3^{* * *} \\
(4.6)\end{array}$ \\
\hline White & $\begin{array}{l}3.1^{*} \\
(1.4)\end{array}$ & $\begin{array}{l}3.3^{*} \\
(1.4)\end{array}$ & $\begin{array}{l}3.3^{*} \\
(1.3)\end{array}$ \\
\hline Age & $\begin{array}{c}0.1^{* *} \\
(0.04)\end{array}$ & $\begin{array}{c}0.1^{*} \\
(0.04)\end{array}$ & $\begin{array}{c}0.1^{*} \\
(0.04)\end{array}$ \\
\hline Female & $\begin{array}{c}4.5^{* * *} \\
(1.2)\end{array}$ & $\begin{array}{c}4.3^{* * *} \\
(1.1)\end{array}$ & $\begin{array}{c}4.3^{* * *} \\
(1.1)\end{array}$ \\
\hline Constant & $\begin{array}{c}53.2^{* * *} \\
(2.9)\end{array}$ & $\begin{array}{c}55.1^{* * *} \\
(3.0)\end{array}$ & $\begin{array}{c}55.4^{* * *} \\
(2.9)\end{array}$ \\
\hline Observations & 1,638 & 1,638 & 1,637 \\
\hline Adjusted $\mathrm{R}^{2}$ & 0.1 & 0.1 & 0.1 \\
\hline
\end{tabular}


As a final effort, to investigate the links in our causal chain, we regress redistributive preferences on the sentiment scores calculated from the quantitative text analysis of respondents' essays in the treatment group. We focus our attention to three dimensions available in the LIWC library: anxiety, sadness, and a general negative emotion score. Given that the sentiment scores are highly right-skewed, we transform them into z-scores. Table OA14 reports highly significant positive associations. It's worth remembering that the maximum of the scale is above 10 for anxiety and sadness, and above 5 for negative emotions, therefore those who wrote the most anxious, sad, or negative essays were substantially more supportive of redistribution than those who wrote the least emotional essays. However, it's worth emphasising again that we do not know whether it is the strong emotional reaction to the task increasing support for redistribution, a strong support for redistribution increasing the emotionality of the essays, or if there are omitted variables affecting both of these factors. 
Table OA14: The relationship between essay sentiment and redistributive preferences

\begin{tabular}{|c|c|c|c|}
\hline & \multicolumn{3}{|c|}{ Dependent variable: } \\
\hline & \multicolumn{3}{|c|}{ Redistributive preferences } \\
\hline & $(1)$ & $(2)$ & $(3)$ \\
\hline Anxiety & $\begin{array}{c}2.0^{* * *} \\
(0.4)\end{array}$ & & \\
\hline Sadness & & $\begin{array}{c}2.1^{* * * *} \\
(0.4)\end{array}$ & \\
\hline Negative emotions & & & $\begin{array}{c}2.9^{* * *} \\
(0.5)\end{array}$ \\
\hline Republican & $\begin{array}{c}-12.1^{\text {*** }} \\
(1.3)\end{array}$ & $\begin{array}{c}-11.7^{* * *} \\
(1.3)\end{array}$ & $\begin{array}{c}-11.9^{* * *} \\
(1.3)\end{array}$ \\
\hline Democrat & $\begin{array}{c}6.3^{* * *} \\
(1.3)\end{array}$ & $\begin{array}{c}6.7^{* * *} \\
(1.3)\end{array}$ & $\begin{array}{c}6.3^{* * * *} \\
(1.3)\end{array}$ \\
\hline Higher Education & $\begin{array}{c}-2.7^{* *} \\
(0.9)\end{array}$ & $\begin{array}{c}-2.5^{* *} \\
(0.9)\end{array}$ & $\begin{array}{c}-2.9^{* *} \\
(0.9)\end{array}$ \\
\hline White & $\begin{array}{c}1.9 \\
(1.0)\end{array}$ & $\begin{array}{l}2.2^{*} \\
(1.0)\end{array}$ & $\begin{array}{c}1.8 \\
(1.0)\end{array}$ \\
\hline Age & $\begin{array}{c}0.1^{* *} \\
(0.03)\end{array}$ & $\begin{array}{c}0.1^{*} \\
(0.03)\end{array}$ & $\begin{array}{c}0.1^{* *} \\
(0.03)\end{array}$ \\
\hline Female & $\begin{array}{c}3.6^{* * *} \\
(0.9)\end{array}$ & $\begin{array}{c}4.0^{* * *} \\
(0.9)\end{array}$ & $\begin{array}{c}3.9^{* * *} \\
(0.9)\end{array}$ \\
\hline Constant & $\begin{array}{c}62.6^{* * *} \\
(1.7)\end{array}$ & $\begin{array}{c}62.8^{* * *} \\
(1.7)\end{array}$ & $\begin{array}{c}62.2^{* * *} \\
(1.7)\end{array}$ \\
\hline Observations & 1,647 & 1,647 & 1,647 \\
\hline Adjusted $\mathrm{R}^{2}$ & 0.2 & 0.2 & 0.2 \\
\hline
\end{tabular}

